\title{
AS SUBFAMÍLIAS VANILLOIDEAE E ORCHIDOIDEAE (ORCHIDACEAE) EM UM FRAGMENTO DA SERRA DA MANTIQUEIRA, MINAS GERAIS, BRASIL
}

\author{
NARJARA LOPES DE ABREU* \& LUIZ MENINI NETO** \\ * Programa de Mestrado em Ecologia da Universidade Federal de Juiz de Fora. Minas Gerais, Brasil (e-mail: narjara_lopes@hotmail.com). \\ ** Centro de Ensino Superior de Juiz de Fora, Campus Arnaldo Jannsen, Luz Interior, 345, Santa Luzia, 36030-776, Juiz de Fora, Minas \\ Gerais, Brasil. Autor para correspondência: menini_neto@hotamil.com.
}

\begin{abstract}
The subfamilies Vanilloideae and Orchidoideae in a fragment of the Serra da Mantiqueira, Minas Gerais, Brazil). At present day Orchidaceae is divided in five sufamilies: Apostasioideae, Cypripedioideae, Vanilloideae, Orchidoideae e Epidendroideae. This survey presents the species of Vanilloideae and Orchidoideae that occurs in a fragment of the Serra da Mantiqueira, in Minas Gerais State. Regular collections were performed in this site between 2003 and 2009 in Serra Negra, among the municipalities of Olaria, Santa Bárbara do Monte Verde, Lima Duarte and Rio Preto, and in Serra do Funil, in Funil village, municipality of Rio Preto. Twenty five species were recorded, 22 within Orchidoideae and three within Vanilloideae. The richest genera were Habenaria (eight spp) and Prescottia (three spp). Six distribution patterns could be observed to the occurring species in study area: 1) neotropical; 2) South America; 3) southeastern and southern Brazil, and Argentina; 4) southeastern and southern Brazil; 5) southeastern Brazil and 6) endemic to Minas Gerais State. Descriptions, identification keys of the subfamilies and species, illustrations and comments are presented.
\end{abstract}

Resumo - (As subfamílias Vanilloideae e Orchidoideae (Orchidaceae) em um fragmento da Serra da Mantiqueira, Minas Gerais, Brasil). Atualmente Orchidaceae é dividida em cinco subfamílias: Apostasioideae, Cypripedioideae, Vanilloideae, Orchidoideae e Epidendroideae. O presente estudo apresenta as espécies de Vanilloideae e Orchidoideae ocorrentes em um fragmento da Serra da Mantiqueira, no estado de Minas Gerais. As coletas foram realizadas entre os anos de 2003 e 2009 na Serra Negra, localizada na divisa dos municípios de Olaria, Santa Bárbara do Monte Verde, Lima Duarte e Rio Preto, e Serra do Funil, no vilarejo do Funil, em Rio Preto. Foi registrado um total de 25 espécies na área estudada, sendo 22 de Orchidoideae e três de Vanilloideae. Os gêneros mais ricos são Habenaria (oito spp) e Prescottia (três sp). Seis padrões de distribuição geográfica puderam ser observados para as espécies registradas na área de estudo: 1) neotropical; 2) América do Sul; 3) regiões sudeste e sul do Brasil e Argentina; 4) regiões sudeste e sul do Brasil; 5) região sudeste do Brasil e 6) restrita ao estado de Minas Gerais. São apresentados descrições, chaves de identificação de subfamílias e espécies, ilustrações e comentários.

Key words: Serra Negra, Serra do Funil, Atlantic Forest, flora.

\section{Introdução}

Orchidaceae Juss. é uma das maiores famílias dentre as Angiospermas, com estimativa de 21950 espécies, distribuídas em aproximadamente 880 gêneros (Pridgeon et al. 1999). Pabst \& Dungs $(1975,1977)$ apontam mais de 2300 espécies e 190 gêneros para o Brasil, que se destaca por ser um dos países mais ricos do mundo em espécies de orquídeas (Dressler 1981).

Cameron et al. (1999) e Pridgeon et al. (1999) dividem Orchidaceae em cinco subfamílias: Apostasioideae, Cypripedioideae, Vanilloideae (abrigando parte das Epidendroideae sensu Dressler (1993), Orchidoideae (englobando as Spiranthoideae sensu Dressler (1993) e Epidendroideae.

Vanilloideae Szlach. é composta por 15 gêneros englobando 175 espécies terrícolas ou hemiepífitas, distribuídas amplamente por todo o mundo, com alguns gêneros apresentando disjunções transcontinentais
(Pridgeon et al. 1999, 2001). Morfologicamente caracterizam-se por possuírem antera incumbente e apenas um estame fértil, além de apresentarem grãos de pólen agregados, porém não formando polínias (Dressler 1993, Cameron et al. 1999, Pridgeon et al. 1999, 2001).

Orchidoideae Eaton apresenta cerca de 3650 espécies majoritariamente terrícolas, distribuídas por 208 gêneros, com ampla distribuição geográfica (Pridgeon et al. 1999, 2001, 2003). Tem como principais características morfológicas a antera ereta, apenas um estame fértil e formação de polínias, com grãos de pólen com maior ou menor grau de união e a presença de viscídio (Dressler 1993, Cameron et al. 1999, Pridgeon et al. 2001, 2003).

Este estudo tem como objetivos apresentar as espécies de Orchidoideae e Vanilloideae ocorrentes em um fragmento da Serra da Mantiqueira formado pela Serra Negra e Serra do Funil, com descrição, ilustração, chaves de identificação e comentários. 


\section{Material e Métodos}

A área de estudo compreende a Serra Negra, localizada na divisa entre os municípios de Lima Duarte, Santa Bárbara do Monte Verde, Rio Preto e Olaria (21 $\left.58^{\prime} 24^{\prime \prime}-43^{\circ} 53^{\prime} 15^{\prime \prime}\right)$, e a Serra do Funil, formada pelos serrotes de Santa Clara e São Gabriel, localizada no vilarejo do Funil, no município de Rio Preto $\left(22^{\circ} 05^{\prime} \mathrm{S}\right.$ e $43^{\circ} 49^{\prime} \mathrm{W}$ ) (Fig. 1). O clima da região é do tipo Cwb de Köppen, mesotérmico úmido, com invernos secos e frios e verões brandos e úmidos. A média de precipitação anual é de 1886mm (Valente 2007).

A região está inserida no complexo serrano da Mantiqueira, com vegetação formada por um mosaico de áreas campestres e formações florestais. A variação altitudinal, que vai de 900 e 1698 m, aliada à variação nos tipos de solos, às diferenças sucessionais e o tempo de permanência da água no solo, contribui para intensa complexidade de habitats.

O estudo fitofisionômico de Valente (2007) revela uma grande riqueza de espécies arbóreas bem como uma especificidade ambiental em cada formação florestal. As formações foram classificadas como Floresta Ombrófila Alto-montana (floresta nebular), Floresta Ombrófila Baixo-montana e Floresta Ombrófila Aluvial. Além destas formações, pode ser reconhecido um trecho peculiar de Floresta Ombrófila Densa, com cerca de 0,9 ha, no Cânion da Gruta do Funil, tratado como floresta de grota (Menini Neto et al. 2009). No entanto ainda existe uma indefinição acerca da classificação das áreas campestres encontradas nesta área, optando-se pela denominação complexo rupestre de altitude sobre quartzito proposto por Benites et al. (2003), porém com influência da floresta atlântica.

Entre os anos de 2003 e 2009, foram realizadas coletas em várias localidades da Serra Negra e Serra do Funil (Tab. 1). Os espécimes férteis coletados foram prensados em

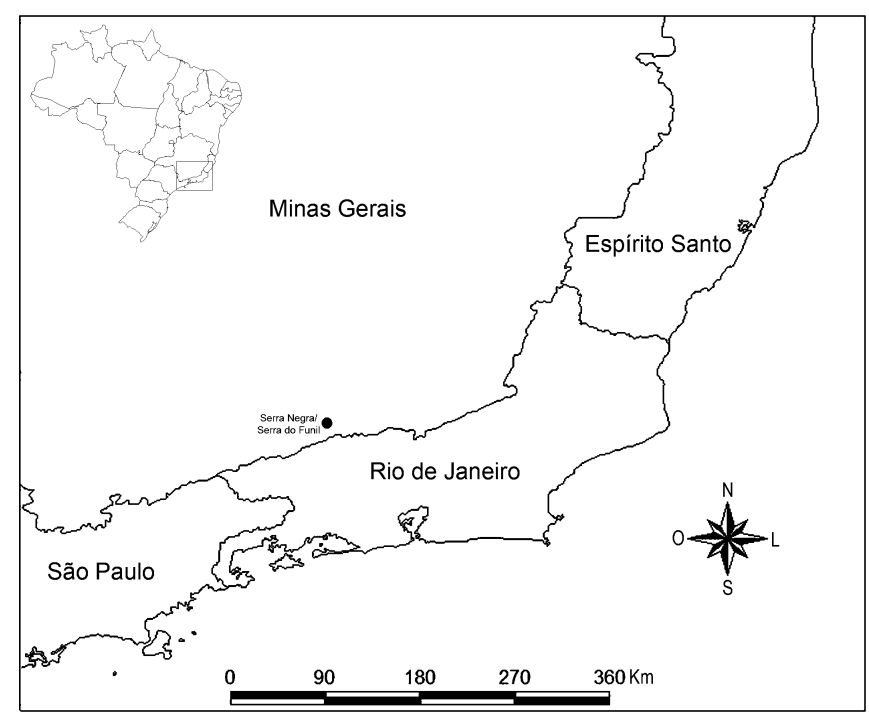

Fig. 1. Localização da área de estudo (Serra Negra/Serra do Funil). campo, algumas flores foram conservadas em álcool a 70\% para análise posterior em laboratório. Os materiais foram herborizados e acondicionados de acordo com a metodologia usual, depositados no Herbário CESJ (acrônimo segundo Holmgren \& Holmgren 1998).

A identificação das espécies e os dados de distribuição geográfica foram obtidos através de consulta à bibliografia especializada, Rodrigues (1877, 1882), Cogniaux (1893-1896, 1898-1902, 1904-1906), Hoehne (1940, 1942, 1945, 1949, 1953), Pabst \& Dungs (1975, 1977), Sprunger (1996), World Checklist of Selected Plant Families (2010), à coleção dos herbários BHCB, CESJ e RB e a especialistas da família. A descrição das espécies e a confecção das ilustrações foram baseadas apenas em material coletado na área de estudo. As plantas com mais de três folhas foram consideradas multifoliadas e as que possuem uma, duas ou três folhas, como paucifoliadas. $\mathrm{O}$ material examinado refere-se às coletas realizadas na Serra Negra-Serra do Funil e está citado em ordem cronológica de coleta.

\section{Resultados e Discussão}

Foram registradas na área de estudo 22 espécies da subfamília Orchidoideae, distribuídas em 11 gêneros, e apenas três espécies pertencentes a dois gêneros de Vanilloideae (Cleistes Rich. ex Lindl. e Pogoniopsis Rchb.f.). Habenaria Willd. é o gênero que possui maior riqueza (oito spp.), seguido de Prescottia Lndl. (três spp.), Aspidogyne Garay e Cleistes Rich. ex Lindl. (duas spp. cada) e o restante dos gêneros, Cranichis Sw., Cyclopogon C. Presl, Eurystyles Wawra, Lankesterella Ames, Mesadenus Schltr., Sacoila Raf., Sarcoglottis C. Presl, Sauroglossum Lindl., Stigmatosema Garay e Pogoniopsis Rchb.f. estão representados por apenas uma espécie.

Até o momento, os representantes das duas subfamílias representam juntos cerca de $24 \%$ do total das espécies de Orchidaceae registradas na área estudada (N. L. Abreu \& L. Menini Neto, dados não publicados). Esta porcentagem pode ser considerada elevada, uma vez que Rocha \& Waechter (2006) destacam que a dificuldade de observação de espécies terrícolas, devido à baixa frequência, isolamento e tamanho geralmente reduzido de seus indivíduos ou pelas plantas perderem suas folhas durante a antese, podem dificultar o registro destas espécies resultando em levantamentos subestimados de Orchidaceae como um todo.

As espécies ocupam os diversos tipos de ambientes encontrados nas matas e nos campos. Apenas Habenaria petalodes Lindl., Sacoila lanceolata (Aubl.) Garay e Habenaria josephensis Barb. Rodr. fram registradas em áreas degradadas, as duas primeiras também reconhecidas pela adaptação em áreas antropizadas por outros autores (Batista et al. 2004, Rocha \& Waechter 2006). Estas três espécies também ocupam a maior variedade de ambientes 
na área de estudo. Apenas Eurystyles actinosophila (Barb. Rodr.) Schltr. e Lankesterella ceracifolia (Barb. Rodr.) Mansf. ocorrem como epífitas, sendo encontradas somente em interior de mata e o restante das espécies são terrícolas e estão divididas de forma aproximadamente semelhante em número, nas áreas campestres (13) e nas formações florestais (12).

À exceção de Habenaria rolfeana Schltr., que forma população com 30-40 indivíduos em uma grande extensão dos campos encontrados acima de $1400 \mathrm{~m}$ de altitude, as outras espécies são pouco freqüentes e não formam populações perceptíveis. Algumas espécies aparecem de forma peculiar na área estudada, ocorrendo em apenas uma região ou associada a uma formação vegetacional ou condição ambiental específica: Prescottia montana Barb. Rodr., pode ser encontrada em várias altitudes da Serra Negra, mas está sempre associada aos campos; E. actinosophila, apesar de ter sido encontrada em formações vegetacionais diferentes, tem sua ocorrência determinada pelo alto grau de umidade das florestas nebulares encontradas acima de $1300 \mathrm{~m}$ de altitude e da Floresta Ombrófila Aluvial (conhecida localmente como Mata de Cambuí); L. ceracifolia está restrita às florestas nebulares encontradas acima de $1300 \mathrm{~m}$ de altitude; Habenaria pseudoglaucophylla J. A. N. Batista, R. C. Mota \& N. Abreu e H. rodeiensis Barb. Rodr. ocorrem apenas na região de campo do entorno da Gruta do Funil; e Cyclopogon warmingii (Rchb.f.) Schltr. e Stigmatosema polyaden (Vell.) Garay são restritas à floresta de grota do Cânion do Funil.

Seis padrões de distribuição puderam ser observados: 1) distribuição neotropical: Prescottia stachyodes (Sw.) Lindl. e Sacoila lanceolata; 2) distribuição na América do Sul: Habenaria parviflora Lindl., $H$. petalodes e H. rodeiensis; 3 ) distribuição nas regiões sudeste e sul do Brasil e Argentina: Cranichis candida (Barb. Rodr.) Cogn., E. actinosophila e S. polyaden; 4) distribuição na floresta atlântica das regiões sudeste e sul do Brasil: Aspidogyne commelinoides (Barb. Rodr.) Garay e Habenaria rolfeana; 5) distribuição na região sudeste do Brasil: A. hylibates (Rchb. f.) Garay, Cleistes gracilis (Barb. Rodr.) Schltr., Cyclopogon warmingii (Rchb. f.) Schltr. e Pogoniopsis cf. nidus-avis Rchb. f.; 6) distribuição restrita ao estado de Minas Gerais: H. pseudoglaucophylla, Prescottia phleoides Lindl. e Sarcoglottis umbrosa (Barb. Rodr.) Schltr.

Embora $H$. pseudoglaucophylla tenha sido descrita após a revisão da lista das espécies ameaçadas de extinção no estado de Minas Gerais (Biodiversitas 2007), seguindo critérios indicados pela International Union for Conservation Nature (IUCN), poderia ser classificada como espécie Em Perigo (Batista et al. 2008). Ainda segundo Biodiversitas (2007), Pogoniopsis nidus-avis aparece listada como espécie Deficiente de Dados. Esta falta de informação sobre as espécies de orquídeas terrestres demonstra a necessidade de maior estudo acerca dos grupos que apresentam esta forma de vida.

Tabela 1 - Principais localidades de coleta na Serra Negra, Minas Gerais, Brasil.

\begin{tabular}{|c|c|c|}
\hline Localidades & Coordenadas geográficas & Municípios \\
\hline Fazenda Tiririca & S $21^{\circ} 58^{\prime} 53^{\prime \prime} \mathrm{W} 43^{\circ} 56^{\prime} 08^{\prime \prime}$ & Rio Preto \\
\hline Gruta do Funil & $\mathrm{S} 22^{\circ} 00^{\prime} 40,4^{\prime \prime} \mathrm{W} 43^{\circ} 53^{\prime} 15,2^{\prime \prime}$ & Rio Preto \\
\hline Mata de Cambuí & S $22^{\circ} 00^{\prime} 07.06^{\prime \prime} \mathrm{W} 43^{\circ} 53^{\prime} 21,13^{\prime \prime}$ & Rio Preto \\
\hline Trilha para o Ninho da Égua & 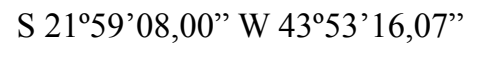 & Rio Preto \\
\hline Ninho da Égua & S $21^{\circ} 58^{\prime} 31,4^{\prime \prime} \mathrm{W} 43^{\circ} 53^{\prime} 28,7^{\prime \prime}$ & Rio Preto \\
\hline Burro de Ouro & $\mathrm{S} 21^{\circ} 58^{\prime} 04,3^{\prime \prime} \mathrm{W} 43^{\circ} 53^{\prime} 13,8^{\prime \prime}$ & Rio Preto - Lima Duarte - Olaria \\
\hline Fazenda da Água Amarela & $\mathrm{S} 22^{\circ} 01^{\prime} 22,2^{\prime \prime} \mathrm{W} 43^{\circ} 51^{\prime} 53,4^{\prime \prime}$ & Rio Preto \\
\hline Fazenda do Mato Limpo & $\mathrm{S} 22^{\circ} 01^{\prime} 46,4^{\prime \prime} \mathrm{W} 43^{\circ} 52^{\prime} 31,5^{\prime \prime}$ & Rio Preto \\
\hline Estrada de acesso ao Vilarejo do Funil & S $22^{\circ} 00^{\prime} 12,4^{\prime \prime} \mathrm{W} 43^{\circ} 52^{\prime} 42,4^{\prime \prime}$ & Rio Preto \\
\hline Fazenda Santa Luiza & S $21^{\circ} 58^{\prime} 40,7^{\prime \prime} \mathrm{W} 43^{\circ} 52^{\prime} 30,7^{\prime}$ & Rio Preto \\
\hline Marciano & 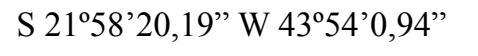 & Rio Preto - Olaria \\
\hline R.P.P.N. São Lourenço do Funil & S $22^{\circ} 00^{\prime} 56,9^{\prime \prime} \mathrm{W} 43^{\circ} 54^{\prime} 10,3^{\prime \prime}$ & Rio Preto \\
\hline R.P.P.N. Serra Negra & S $21^{\circ} 56^{\prime} 06,6^{\prime \prime} \mathrm{W} 43^{\circ} 50^{\prime} 12,2^{\prime \prime}$ & Lima Duarte \\
\hline
\end{tabular}


Chave de identificação das subfamílias

1. Coluna incumbente, grãos de pólen não formando polínias Vanilloideae

1'. Coluna ereta, grãos de pólen unidos, formando polínias Orchidoideae

Chave de identificação das espécies da subfamília Vanilloideae

1. Erva aclorofilada micoheterotrófica, multifoliada, lâmina foliar adpressa, inflorescência multiflora.........Pogoniopsis cf. nidus-avis

1'. Erva clorofilada, paucifoliada, lâmina foliar patente, flores solitárias ou inflorescência com uma ou duas flores ... Cleistes

2. Crista central do labelo amarela, lobo mediano do labelo ungüiculado, ca. 9 × $8 \mathrm{~mm}$ C. gracilis

2'. Crista central do labelo alva, lobo mediano do labelo reduzido, ca. 3 × $3 \mathrm{~mm}$...... C. moritzii

Cleistes gracilis (Barb. Rodr.) Schltr., Arch. Bot. São Paulo 1: 179. 1926.

Cleistes paulensis Schltr., Arch. Bot. Est. São Paulo 1: 180. 1926.

Cleistes ionoglossa Hoehne \& Schltr., Arch. Bot. São Paulo 1: 181. 1926.

Cleistes carautae Toscano \& Leoni, Pabstia 3(5): 1. 1997.

Fig. 2. A

Terrícola, clorofilada. Caule cilíndrico, paucifoliado, ca. $15,5 \mathrm{~cm}$ compr. Folhas alternas dísticas, sésseis. Lâmina foliar verde, membranácea, patente, ca. 5,5 x 0,7 cm, lanceolada, ápice agudo. Flor solitária; pedicelo ca. $5 \mathrm{~mm}$ compr.; sépala dorsal rósea, ca. $2,9 \times 0,5 \mathrm{~cm}$, estreitamente elíptica, ápice agudo; sépalas laterais róseas, ca. $2,7 \times 0,5 \mathrm{~cm}$, estreitamente elípticas, ápice agudo; pétalas róseas, ca. 2,7 x 0,8 cm, oblanceoladas, levemente assimétricas, ápice agudo; labelo 3-lobado, ca. 2,7 x $0,9 \mathrm{~cm}$, duas glândulas nectaríferas globosas na base, crista central amarela ao longo do comprimento, no terço distal a crista torna-se papilosa, lobos laterais ca. 1,9 cm compr., ápice agudo, lobo mediano ca. $9 \times 8 \mathrm{~mm}$, largamente ovado, ungüiculado, margem irregularmente denteada. Fruto não visto.

Material examinado: Minas Gerais: Rio Preto, Serra Negra, 10.IV.2007, bot., Abreu et al. 173 (CESJ).

Distribuição geográfica: MG, SP, RJ (Pansarin 2005).

Cleistes gracilis foi encontrada a cerca de $1400 \mathrm{~m}$ de altitude, sendo observado apenas um indivíduo isolado, no campo úmido, entre pteridófitas, ambiente preferencial desta espécie, segundo Pansarin (2005). A crista central evidente ao longo do labelo, geralmente amarelo-esverdeada e seu lobo central irregularmente denteado distinguem $C$. gracilis de $C$. moritzii (Pansarin 2005). Além disso, C. gracilis apresenta um porte menor em relação C. moritizii.

Cleistes moritzii (Rchb. f.) Garay \& Dunst., Venez. Orchid. Ill. 4: 54. 1966.

Cleistes pluriflora (Barb. Rodr.) Schltr., Arch. Bot. São Paulo 1: 179. 1926.

Fig. 2.B

Terrícola, clorofilada. Caule cilíndrico, multifoliado, ca. $46 \mathrm{~cm}$ compr. Folhas alternas dísticas, sésseis. Lâmina foliar verde, membranácea, patente, $3,5-7,5 \times 1-1,5 \mathrm{~cm}$, lanceolada, ápice agudo. Inflorescência racemosa, ereta, laxa, apical, uniflora ou biflora, ca. 2,5 cm compr.; pedúnculo inconspícuo; pedicelo inconspícuo; sépala dorsal rósea, ca. $2,3 \times 0,5 \mathrm{~cm}$, lanceolada, ápice agudo.; sépalas laterais róseas, ca. 2,3 x 0,4 $\mathrm{cm}$, lanceoladas, ápice agudo; pétalas róseas, ca. 2,2 x 0,7 cm, elípticas, ápice acuminado; labelo róseo, 3-lobado, ca. 2,2 x 1 $\mathrm{cm}$, elíptico, duas glândulas nectaríferas na base, crista central alva ao longo do comprimento, no terço distal a crista torna-se papilosa, lobos laterais ca. $1,8 \times 0,4 \mathrm{~cm}$, estreitamente oblongos, lobo mediano ca. 3 × 3 mm, ovado, ápice agudo. Fruto não visto.

Material examinado: Minas Gerais: Rio Preto, Serra Negra, 25.IV.2005, fl., Abreu et al. 7 (CESJ); 1.IV.2006, fl., Viana et al. 2022 (CESJ).

Distribuição geográfica: BA, MG, RJ, América Central (Pansarin 2005).

Foram encontrados indivíduos em campo e em áreas de transição. Pansarin (2005) cita também sua ocorrência em campos alagados. Atingem um porte maior do que $C$. gracilis, e possuem o lobo mediano reduzido.

Pogoniopsis cf. nidus-avis Rchb.f., Otia Bot. Hamburg.: 82. 1881.

Fig. 2. C

Micoheterotrófica, aclorofilada. Caule cilíndrico, 8-17 $\mathrm{cm}$ compr., multifoliado. Folhas sésseis, alternas. Lâmina foliar adpressa, cartácea, 1,5-2 x 0,5-0,6 cm, de lanceoladas a ovadas, ápice agudo. Inflorescência racemosa, ereta, laxa, apical, pauciflora, 3-6 cm compr.; pedúnculo ca. $1 \mathrm{~cm}$ compr.; pedicelo ca. $5 \mathrm{~mm}$ compr; flores passadas. Frutos em formação, amarelos, glabros, perianto persistente, $1-1,8 \mathrm{~cm}$ compr.

Material examinado: Minas Gerais: Rio Preto, Serra Negra, 21.V.2006, fr., Santiago et al. 11 (CESJ).

Distribuição geográfica: MG (Pabst \& Dungs 1975).

Única espécie micoheterotrófica da SN/SF. Foi coletada em interior de mata formando grande população. Pode ser facilmente diferenciada das demais espécies registradas na área por ser aclorofilada. 

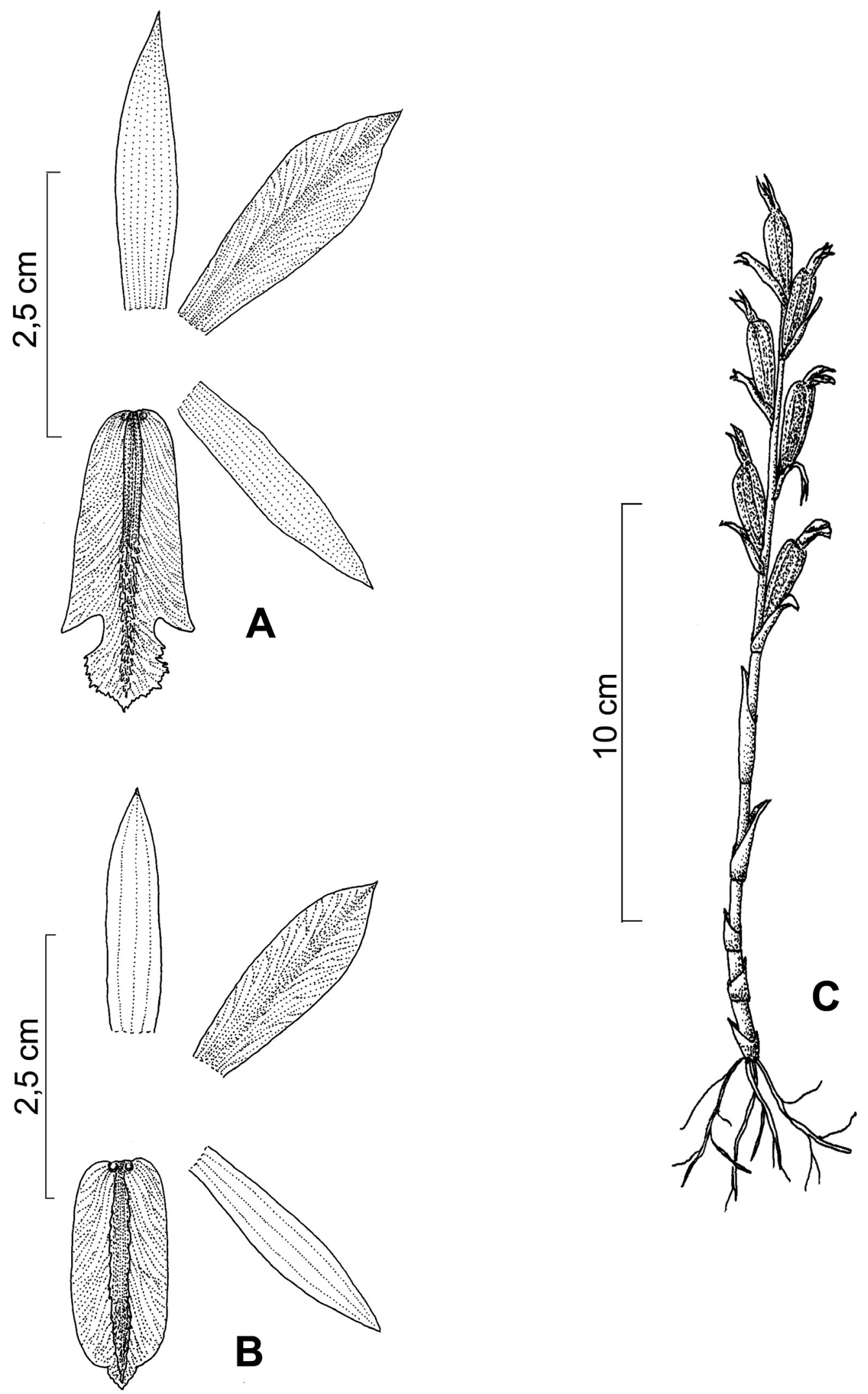

Fig. 2. Subfamília Vanilloideae: A. Cleistes gracilis - perianto dissecado; B. C. moritzii - perianto dissecado; C. Pogoniopsis cf. nidus-avis aspecto geral. (A. Abreu et al. 173; B. Abreu et al. 7; C. Santiago et al. 11). 
Chave de identificação das espécies da subfamília Orchidoideae

1. Erva epífita, até $4 \mathrm{~cm}$ alt., folhas com margem ciliada.

2. Inflorescência capituliforme, com mais de duas flores Eurystyles actinosophila

2'. Inflorescência racemosa, 1-2-flora Lankesterella ceracifolia

1'. Erva terrícola, maior que $20 \mathrm{~cm}$ alt., folhas com margem inteira.

3. Labelo com cálcar.

4. Tuberóide presente, flores glabras, pétalas bífidas, com ápice agudo, ou quando inteiras, com ápice truncado ....Habenaria 5. Labelo sem lobos H. petalodes

5'. Labelo com lobos.

6. Segmento mediano do labelo maior que os segmentos laterais.

7. Segmentos laterais do labelo maiores que a metade do segmento mediano, segmento mediano, ca. $2 \mathrm{~mm}$ compr, obovado H. parviflora

7'. Segmentos laterais do labelo menores que a metade do segmento mediano, segmento mediano, ca. $6 \mathrm{~mm}$ compr, estreitamente oblongo H. josephensis

6'. Segmento mediano do labelo menor que os segmentos laterais.

8. Segmento inferior das pétalas maior que o segmento superior. 9. Folhas rosuladas, pedicelo inconspícuo H. pseudoglaucophylla

9'. Folhas alternas dísticas, pedicelo rígido, ca. $2,5 \mathrm{~cm}$ compr. H. rodeiensis

8 '. Segmento inferior das pétalas menor que o segmento superior.

10. Lâmina foliar linear, apressa ao caule, inflorescência até 10 flores H. rolfeana 10'. Lâmina foliar lanceolada, patente, inflorescência com mais de 10 flores.

11. Cálcar até $2,5 \mathrm{~cm}$ compr., sépalas com aproximadamente o mesmo compr., ca 7,5 mm H. warmingii 11'. Cálcar com mais de $7 \mathrm{~cm}$ compr., sépala dorsal menor que as sépalas laterais, sépala dorsal ca. $1,4 \mathrm{~cm}$ compr. H. macronectar

4'. Tuberóide ausente, pedicelo, ovário e sépalas pilosos, pétalas inteiras, com ápice agudo Aspidogyne

12. Inflorescência multiflora, flores alaranjadas, cálcar com o ápice abruptamente dilatado .............. commelinoides

12'. Inflorescência pauciflora, flores alvo-esverdeadas, cálcar com dilatação gradual, pouco acentuada .. A. hylibates 3'. Labelo sem cálcar.

13. Flores não ressupinadas, labelo cuculado ou côncavo.

14. Inflorescência em racemo, sépalas e pétalas retas, superfície do labelo verruculosa Cranichis candida

14'. Inflorescência em espiga, sépalas e pétalas fortemente recurvadas, superfície do labelo lisa Prescottia

15. Planta unifoliada P. montana

15'. Planta paucifoliada.

16. Folha verde-escura, margem com uma fina listra alva, pseudopecíolo 10-13 cm compr., inflorescência ca. $76 \mathrm{~cm}$ compr. P. stachyodes

16'. Folhas verde-claras, pseudopecíolo 5-6 cm compr., inflorescência ca. $47 \mathrm{~cm}$ compr.

13'. Flores ressupinadas, labelo plano.

17. Plantas áfilas na antese, flores róseas P. phleoides

17'. Plantas com folhas na antese, flores alvas, creme ou verdes.

18. Folhas verdes, esparsamente maculadas de creme, labelo com ápice recurvado

18 '. Folhas inteiramente verdes ou variegadas, labelo com ápice ereto.

19. Inflorescência secunda

19'. Inflorescência com flores espiraladas.

20. Folhas variegadas, largamente elípticas, até $3,5 \mathrm{~cm}$ compr. Sacoila lanceolata

20 '. Folhas verdes, estreitamente elípticas, maiores que $10 \mathrm{~cm}$ compr.

21. Caule 2-foliado, pseudopecíolo ca. $21 \mathrm{~cm}$ compr., inflorescência até $62 \mathrm{~cm}$ compr. Sarcoglottis umbrosa

21'. Caule multifoliado, pseudopecíolo ca. $8 \mathrm{~cm}$ compr., inflorescência maior que $80 \mathrm{~cm}$ compr. 
Aspidogyne commelinoides (Barb. Rodr.) Garay, Bradea 2: 201. 1977.

Physurus commelinoides Barb.Rodr., Gen. Spec. Orchid. 1: 193.1877.

Erythrodes commelinoides (Barb.Rodr.) Ames, Orchidaceae 7: 70. 1922.

Fig. 3.A

Terrícola, ca. $34 \mathrm{~cm}$ compr. Caule cilíndrico, multifoliado, ca. $20 \mathrm{~cm}$ compr. Folhas espiraladas, pseudopecioladas; pseudopecíolo ca. $2,5 \mathrm{~cm}$ compr. Lâmina foliar verde, membranácea, margem inteira, 6,5-7,5 x 2,4-2,5 cm, lanceolada, ápice agudo. Inflorescência racemosa, ereta, laxa, apical, multiflora, ca. 13,5 cm compr.; pedúnculo ca. $6,5 \mathrm{~cm}$ compr.; pedicelo ca. $3 \mathrm{~mm}$ compr.; sépala dorsal castanha, ca. $9 \times 5 \mathrm{~mm}$, rômbica, face adaxial pilosa, ápice arredondado; sépalas laterais castanhas, ca. 1 x $0,3 \mathrm{~cm}$, estreitamente elípticas, face adaxial pilosa, ápice arredondado; pétalas amarelas, ca. $9 \times 3 \mathrm{~mm}$, oblanceoladas, assimétricas, ápice agudo; labelo castanho, disco amarelo, 3-lobado, ca. 8 × 6 $\mathrm{mm}$, lobos laterais ca. 5,5 $\mathrm{mm}$ compr., reniformes, lobo mediano ca. 2,5 × $3 \mathrm{~mm}$, ovado, ápice agudo; cálcar, clavado, ca. $1,4 \mathrm{~cm}$ compr., ca. $3 \mathrm{~mm}$ larg. na parte mais alargada. Fruto não visto.

Material examinado: Minas Gerais: Rio Preto, Serra Negra, 25.III.2006, fl., Abreu et al. 67 (CESJ).

Distribuição geográfica: RJ, SP, MG (Pabst \& Dungs 1975).

Planta coletada em interior de Floresta Ombrófila AltoMontana, sendo encontrado apenas um indivíduo isolado. Diferencia-se de $A$. hylibates por apresentar flores alaranjadas, em inflorescência multiflora e pelo cálcar com acentuada dilatação na metade apical.

Aspidogyne hylibates (Rchb. f.) Garay, Bradea 2: 202. 1977.

Physurus hylibates Rchb.f., Otia Bot. Hamburg.: 83. 1881.

Erythrodes hylibates (Rchb.f.) Garay \& Pabst, Orquídea (Rio de Janeiro) 18: 214. 1957.

Fig. 3.B

Terrícola, ca. $13 \mathrm{~cm}$ compr. Caule cilíndrico, multifoliado, ca. $9 \mathrm{~cm}$ compr. Folhas espiraladas, pseudopecioladas; pseudopecíolo ca, $2 \mathrm{~cm}$ compr. Lâmina foliar verde-clara, membranácea, margem inteira, 3,4-5 x 1,6-1,7 cm, lanceolada, ápice agudo. Inflorescência racemosa, ereta, laxa, apical, pauciflora, ca. 3,9 cm compr.; pedúnculo ca. $1,2 \mathrm{~cm}$ compr.; pedicelo ca. $2 \mathrm{~mm}$ compr.; sépala dorsal alvo-esverdeada, ca. 6 x $2 \mathrm{~mm}$, ovada, estrigosa na face abaxial, ápice agudo; sépalas laterais alvo-esverdeadas, ca. 7 × $3 \mathrm{~mm}$, elípticas, estrigosas na face abaxial, ápice agudo; pétalas alvo-esverdeadas, ca. $6 \times 1,8 \mathrm{~mm}$, estreitamente elípticas, levemente assimétricas, ápice agudo; labelo alvo-esverdeado, ca. 6 x 3,5 mm, de âmbito elíptico, constrição próxima ao ápice, ápice agudo; cálcar levemente clavado, ca. $7 \mathrm{~mm}$ compr. Fruto não visto.
Material examinado: Minas Gerais: Rio Preto, Serra Negra, 22.II.2004, bot., Assis et al. 991 (CESJ).

Distribuição geográfica: RJ, SP, MG (Pabst \& Dungs 1975).

Aspidogyne hylibates foi coletada em interior da mata, à beira de curso d'água. Diferencia-se de A. hylibates por apresentar flores verdes em inflorescência pauciflora e pelo cálcar com dilatação gradual em direção ao ápice.

Cranichis candida (Barb. Rodr.) Cogn., Fl. bras. 3: 6: 248. 1895.

Fig. 3.C

Terrícola, 27-33 cm compr. Caule inconspícuo, 3-foliado a multifoliado. Folhas rosuladas, pseudopecioladas; pseudopecíolo 2,5-5 cm compr. Lâmina foliar verde, membranácea, margem inteira, 6-7 x ca. 3,5 cm, elíptica, ápice agudo. Inflorescência racemosa, ereta, laxa, lateral, multiflora, $27-33 \mathrm{~cm}$ compr.; pedúnculo ca. $9 \mathrm{~cm}$ compr.; pedicelo ca. $2 \mathrm{~mm}$ compr.; sépala dorsal alva com ápice verde, ca. 2 x 1 $\mathrm{mm}$, elíptica, ápice agudo; sépalas laterais alvas com ápice verde, ca. $2,5 \times 1 \mathrm{~mm}$, estreitamente elípticas, ápice agudo; pétalas alvas, ca. 2 × $0,7 \mathrm{~mm}$, estreitamente oblongas, ápice arredondado; labelo alvo, pintalgado de verde, ca. 3 × 2 mm, elíptico, verruculoso, côncavo, margem involuta, ápice agudo. Fruto não visto.

Material examinado: Minas Gerais: Rio Preto, Serra Negra, 18.V.2006, fl., Abreu et al. 100 (CESJ); 3.VI.2006, fl., Konno et al. 869 (CESJ); 22.VIII.2006, fr., Abreu et al. 104 (CESJ).

Distribuição geográfica: DF, MG, RJ, SP, PR, SC, RS (Pabst \& Dungs 1975), Argentina (World Checklist of Selected Plant Families 2010).

Foram encontrados indivíduos isolados de $C$. candida somente em interior de Floresta Ombrófila, ao longo da trilha que leva ao Ninho da Égua e na região do Burro de Ouro. É uma espécie bastante comum, de modo que outros estudos mostram sua ocorrência em formações variadas, sempre em interior de mata, porém com diferentes condições de umidade. Batista \& Bianchetti (2003) citam sua ocorrência nas matas secas do Distrito Federal, Rocha \& Waechter (2006) nas florestas paludosas e pluviais da planície do Rio Grande do Sul e Menini Neto et al. (2007) nas matas ciliares no Parque Estadual do Ibitipoca, demonstrando sua capacidade de se adaptar a variados tipos de ambientes.

Cyclopogon warmingii (Rchb. f.) Schltr., Beih. Bot. Centralbl. 37: 396. 1920.

Beadlea warmingii (Rchb.f.) Garay, Bot. Mus. Leafl. 28: 301. 1980 (publ. 1982).

Fig. 3.D 
Terrícola, ca. $34-43 \mathrm{~cm}$ compr. Caule inconspícuo, 3-foliado a multifoiado. Folhas rosuladas, pseudopecioladas; pseudopecíolo ca. $6,5 \mathrm{~cm}$ compr. Lâmina foliar verde, membranácea, margem inteira, 9-11 x 1,5$2 \mathrm{~cm}$, estreitamente elíptica, ápice agudo. Inflorescência racemosa, levemente curva, laxa, apical, multiflora, secunda, 34-43 cm compr.; pedúnculo ca. $31 \mathrm{~cm}$ compr.; pedicelo ca. $3 \mathrm{~mm}$ compr.; sépala dorsal verde-escuro, ca. $7 \times 2 \mathrm{~mm}$, lanceolada com uma constrição próxima à base, ápice agudo; sépalas laterais verde-claro, ca. $8 \times 2 \mathrm{~mm}$, lanceoladas, estrigosas, assimétricas, ápice agudo; pétalas verde-claro, ca. $6 \times 1 \mathrm{~mm}$, oblanceoladas, coniventes à sépala dorsal, assimétricas, ápice arredondado. Labelo verde-claro, passando a alvo, ca. $8,5 \times 4 \mathrm{~mm}$, panduriforme, margem involuta, duas projeções chifriformes próximas à sua base, retrorsas, ápice expandido lateralmente, crenado. Fruto não visto.

Material examinado: Minas Gerais: Rio Preto, Serra do Funil, 20.VIII.2004, bot., Matozinhos et al. 19 (CESJ); 18.IV.2006, fl., Abreu et al. 78 (CESJ).

Distribuição geográfica: RJ, SP, MG (Pabst \& Dungs 1975).

Espécie encontrada somente no Cânion da Gruta do Funil, em mata de grota. A lâmina foliar estreitamente elíptica, com um longo pseudopecíolo e inflorescência secunda são características que distinguem $C$. warmingii das demais espécies de orquídeas registradas na área de estudo.

Eurystyles actinosophila (Barb. Rodr.) Schltr., Repert. Spec. Nov. Regni Veg. Beih. 35: 39. 1925.

Fig. 3.E

Epífita, cespitosa, ca. $3,5 \mathrm{~cm}$ compr. Caule inconspícuo, multifoliado. Folhas rosuladas, sésseis. Lâmina foliar glauca, membranácea, ciliada, 2,5-3,5 x 0,9-1,2 cm, oblanceolada à obovada, ápice acuminado. Inflorescência em capítulo, pendente, apical, multiflora, ca. $3,5 \mathrm{~cm}$ compr.; pedúnculo ca. $2,5 \mathrm{~cm}$ compr.; pedicelo inconspícuo; sépala dorsal alva, ca. $4 \times 1 \mathrm{~mm}$, lanceolada, ápice agudo; sépalas laterais alvas, ca. $5 \times 1 \mathrm{~mm}$, lanceoladas, ápice agudo; pétalas alvas, ca. $3 \mathrm{x}$ $0,5 \mathrm{~mm}$, oblanceoladas, coniventes com a sépala dorsal, ápice arredondado; labelo alvo, 3-lobado, ca. 5 x $1 \mathrm{~mm}$, âmbito estreitamente oblongo, aurículas laterais, ca. $1 \mathrm{~mm}$, basais, voltadas para trás, lobo mediano papiloso, ca. 1,4 x 1,2 mm. Fruto não visto.

Material examinado: Minas Gerais: Rio Preto, Serra Negra, 21.V.2006, fl., Santiago et al. 4 (CESJ); 17.III.2007, fl., Menini Neto et al. 431 (CESJ).

Distribuição geográfica: estados da região Sul e Sudeste do Brasil, até Argentina (Pabst \& Dungs 1975, World Checklist of Selected Plant Families 2010).
Miller et al. (2006) citam a preferência desta espécie pelas partes mais baixas dos troncos das árvores e por locais com significativa umidade. Estas condições ambientais também foram observadas nos locais de ocorrência de E. actinosophila na área de estudo, como é o caso das florestas nebulares da região do Burro de Ouro e da mata de Cambuí. Junto com Lankesterella ceracifolia é a menor espécie observada na área de estudo, diferindo dela pela presença de flores muito pequenas em capítulo.

Habenaria josephensis Barb. Rodr., Gen. Sp. Orchid. 2: 257. 1881.

Habenaria wacketii Porsch, Oesterr. Bot. Z. 55: 150. 1905.

Habenaria bradeana Kraenzl., Ark. Bot. 14(10): 3. 1915.

Habenaria heterophylla Schltr., Repert. Spec. Nov. Regni Veg. 16: 253. 1919.

Habenaria foliosissima Kraenzl., Ark. Bot. 16(8): 4. 1921. Habenaria paranaguensis Hoehne, Arq. Bot. Estado São Paulo 2: 105. 1950.

Fig. 3.F-G

Terrícola, 53-143 cm compr. Caule ca. $38-94 \mathrm{~cm}$ compr., cilíndrico, multifoliado. Folhas espiraladas, sésseis. Lâmina foliar verde, membranácea, margem inteira, 8,5-15,5 x 2,8-2,4 cm, elípticas a estreitamente elípticas, ápice agudo. Inflorescência racemosa, ereta, laxa, apical, multiflora, ca. $30 \mathrm{~cm}$ compr.; pedúnculo ca. $21,5 \mathrm{~cm}$ compr.; pedicelo ca. $2 \mathrm{~mm}$ compr.; sépala dorsal verde-claro, ca. $3,5 \times 3 \mathrm{~mm}$, sub-orbicular, cuculada, ápice arredondado a obtuso; sépalas laterais verde-claro, ca. $6 \times 3 \mathrm{~mm}$, falciformes, levemente côncavas, margem inferior involuta, ápice mucronado; pétalas bipartidas, verde-claras, segmento anterior ca. $0,5 \times 0,3 \mathrm{~mm}$, ápice agudo, segmento posterior assimétrico, ca. $3 \times 1,5 \mathrm{~mm}$, oblongo, ápice truncado com pequeno apículo; labelo carnoso, verde-claro, tripartido, com os segmentos laterais pouco ou bem desenvolvidos, segmentos laterais ca. $2 \mathrm{~mm}$ compr., lineares, segmento mediano ca. $6 \times 1$ $\mathrm{mm}$, estreitamente oblongo ápice truncado com pequeno apículo; cálcar ca. $9 \mathrm{~mm}$ compr. Frutos não vistos.

Material examinado: Minas Gerais: Rio Preto, Serra Negra, 26.II.2006, fl., Viana \& Mota 1907 (CESJ); 18.IV.2006, fl., Menini Neto et al. 180 (CESJ); 10.IV.2007, fl., Abreu et al. 190 (CESJ).

Distribuição geográfica: BA, ES, MG, PE, PB, PR, RJ, RS, SC, SP (Batista \& Bianchetti 2002).

Dentre as espécies do gênero encontradas na Serra Negra, Habenaria josephensis, é a que atinge o maior porte, variando de 0,66-1,45 m alt. Foi coletada em interior de Floresta Ombrófila Densa, na região do Burro de Ouro e nas bordas da trilha que leva à região do Ninho da Égua. Foram observadas tanto no campo, quanto em áreas de transição da mata com o campo. Os indivíduos foram encontrados isolados e na faixa entre 1200 e $1600 \mathrm{~m}$ de altitude. 

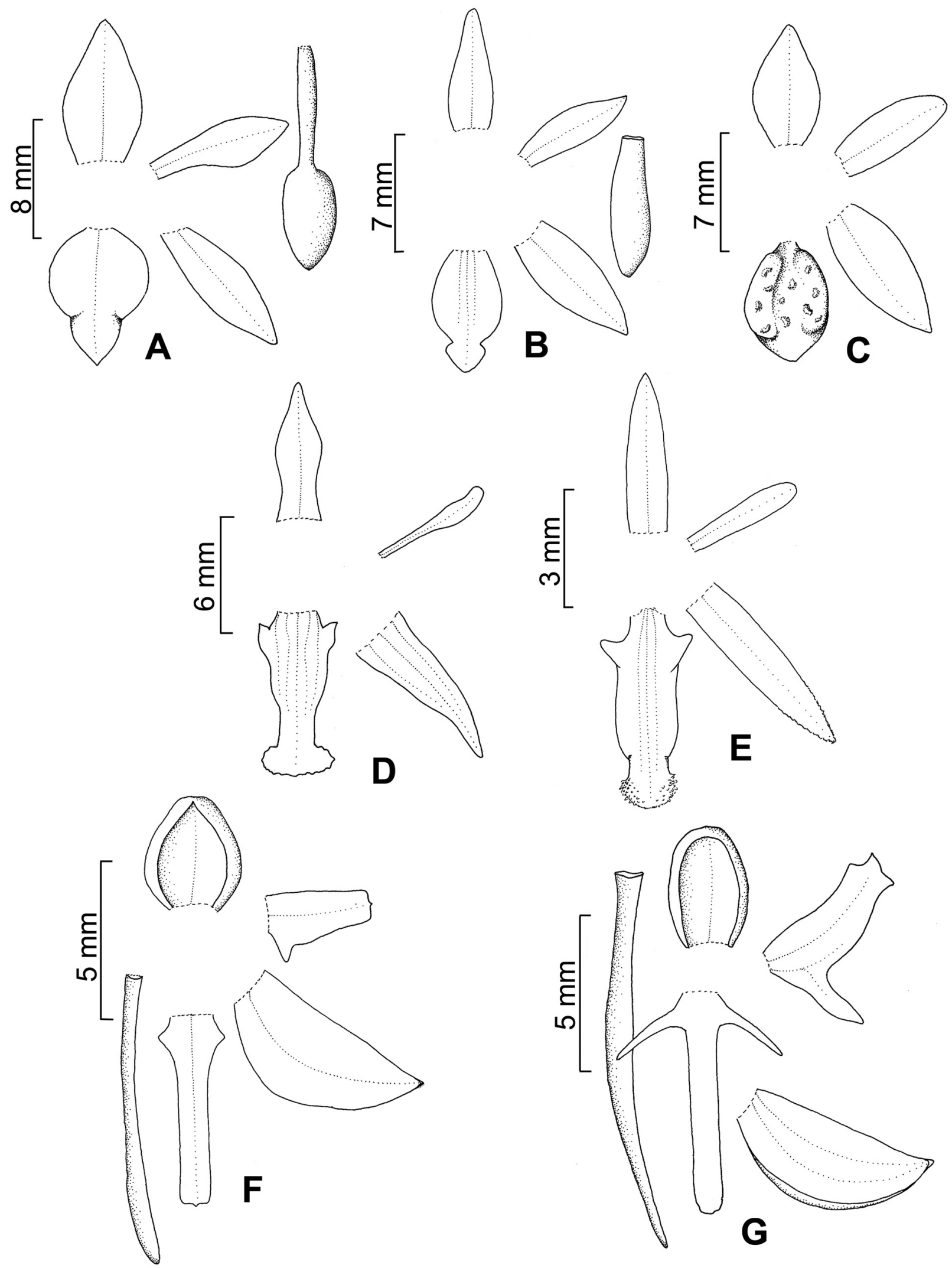

Fig. 3. Subfamília Orchidoideae: A. Aspidogyne commelinoides-perianto dissecado; B. A. hylibates-perianto dissecado; C. Cranichis candida - perianto dissecado; D. Cyclopogon warmingii - perianto dissecado; E. Eurystyles actinosophila - perianto dissecado; F-G. Habenaria josephensis - perianto dissecado. (A. Abreu et al. 67; B. Assis et al. 991; C. Abreu et al. 100; D. Abreu et al. 78; E. Menini Neto et al. 431; F. Menini Neto et al. 180; G. Abreu et al. 190). 
Habenaria macronectar (Vell.) Hoehne, Bot. Jahrb. Syst. 68: 128.1937.

Fig. 4.A

Terrícola, ca. $52 \mathrm{~cm}$ compr. Caule quadrangular, ca. 17 cm compr., multifoliado. Folhas espiraladas, sésseis. Lâmina foliar verde, membranácea, margem inteira, 7-10 x 1,5-2,5 $\mathrm{cm}$, lanceolada, ápice agudo. Inflorescência racemosa, ereta, laxa, apical, multiflora, ca. $35 \mathrm{~cm}$ compr.; pedúnculo ca. 4 cm compr.; pedicelo ca. $1 \mathrm{~cm}$ compr.; sépala dorsal verde, ca. 1,4 x 0,8 cm, elíptica, cuculada, ápice mucronado; sépalas laterais verdes, ca. $1,9 \times 0,8 \mathrm{~cm}$, elípticas, assimétricas, ápice mucronado; pétalas bipartidas amarelas, segmento anterior ca. 2,7 cm compr., filiforme, segmento posterior ca. 1,6 x 0,2 $\mathrm{cm}$, falciforme, conivente à sépala dorsal, ápice mucronado; labelo creme, tripartido, segmentos laterais ca. $2,8 \times 0,1 \mathrm{~cm}$, filiformes, segmento mediano ca. $1,6 \times 0,1 \mathrm{~cm}$, filiforme, carnoso, porção indivisa do labelo ca. $6 \mathrm{~mm}$ compr.; cálcar ca. $7 \mathrm{~cm}$ compr. Frutos não vistos.

Material examinado: Minas Gerais: Rio Preto, Serra Negra, 26.I.2007, fl., Salimena \& Nobre 2369 (CESJ).

Distribuição geográfica: estados das regiões Sul e Sudeste do Brasil e Uruguai (Batista \& Bianchetti 2002, World Checklist of Selected Plant Families 2010).

Habenaria macronectar é uma espécie rara na área de estudo, coletada apenas na Fazenda Tiririca, à beira do curso d'água. Outros estudos apontam também a raridade desta espécie e a preferência por ambientes úmidos, próximos a cursos d'água, como no município de Carangola (Leoni 1990), Parque Estadual do Itacolomi (Batista et al. 2004) e na Mata do Baú (Menini Neto et al. 2004b). Possui porte médio, distinguindo-se das outras espécies da Serra Negra por possuir um cálcar muito longo em relação ao tamanho da flor.

Habenaria parviflora Lindl., Gen. Sp. Orchid. Pl. 314. 1835.

Habenaria montevidensis f. parviflora (Lindl.) Pabst, Orquídea (Rio de Janeiro) 19: 84, 1957.

Fig. 4.B

Terrícola, ca. $37 \mathrm{~cm}$ compr. Caule cilíndrico, ca. 21 cm compr., multifoliado. Folhas alternas, sésseis. Lâmina foliar membranácea, margem inteira, $6,5-11,5 \times 0,6-0,8 \mathrm{~cm}$, estreitamente elíptica, ápice agudo. Inflorescência racemosa, ereta, laxa, apical, multiflora, ca. $16 \mathrm{~cm}$ compr.; pedúnculo ca. $12 \mathrm{~cm}$ compr.; pedicelo ca. $1 \mathrm{~mm}$ compr.; sépala dorsal verde-claro, ca. $3 \times 2 \mathrm{~mm}$, elíptica, levemente côncava, ápice cuspidado ou arredondado; sépalas laterais verdeclaras, ca. 3 x 1,7 mm, falciformes, levemente côncavas, ápice mucronado; pétalas verdes-claras, bipartidas, segmento anterior ca. 1 x $0,1 \mathrm{~mm}$, linear, segmento posterior ca. 3 x $1 \mathrm{~mm}$, lanceolado, assimétrico, ápice agudo; labelo verdeclaro, tripartido, carnoso, segmentos laterais ca. 2 × 0,2 mm, lineares, segmento mediano ca. $2,4 \times 1 \mathrm{~mm}$, obovado, ápice agudo; cálcar ca. $6 \mathrm{~mm}$ compr. Fruto não visto.
Material examinado: Minas Gerais: Rio Preto, Serra Negra, 27.I.2007, fl., Menini Neto et al. 293 (CESJ).

Distribuição geográfica: América do Sul (World Checklist of Selected Plant Families 2010).

Espécie rara na área de estudo, coletada na região do Burro de Ouro, em campo encharcado. Foram encontrados apenas indivíduos de pequeno porte, porém Batista et al. (2004) e Rocha \& Waechter (2006), chamam atenção à variação no porte desta espécie. Em ambos os estudos, H. parviflora também é encontrada em locais úmidos. Diferencia-se principalmente por apresentar as menores flores dentre as espécies de Habenaria registradas na área.

Habenaria petalodes Lindl., Gen. Sp. Orchid. Pl. 316. 1835.

Fig. 4.C

Terrícola, $35-84 \mathrm{~cm}$ compr. Caule cilíndrico, $19-58 \mathrm{~cm}$ compr., multifoliado. Folhas espiraladas, sésseis. Lâmina foliar membranácea, margem inteira, 6,5-13 x 2-4,5 $\mathrm{cm}$, estreitamente elíptica, ápice agudo. Inflorescência racemosa, ereta, laxa, apical, multiflora, 23-19,5 cm compr.; pedúnculo ca. 11,5 cm compr.; pedicelo ca. $5 \mathrm{~mm}$ compr.; sépala dorsal verde-amarelado, ca. 7 × $6 \mathrm{~mm}$, largamente elíptica, ápice retuso; sépalas laterais verde-amareladas, ca. $9 \times 4 \mathrm{~mm}$, falciformes, ápice agudo; pétalas indivisas, verdeamareladas, ca. $8 \times 6 \mathrm{~mm}$, amplamente ovóides, assimétricas, ápice emarginado; labelo indiviso, verde amarelado, ca. 1,4 x $0,1 \mathrm{~cm}$, linear, carnoso; cálcar ca. $2,5 \mathrm{~cm}$ compr. Fruto não visto.

Material examinado: Minas Gerais: Rio Preto, Serra do Funil, 17.IV.2006, fl., Abreu et al. 75 (CESJ); 16.II.2007, bot., Salimena et al. 2412 (CESJ); 26.06.2008, fl., Souza 516 (CESJ).

Distribuição geográfica: América do Sul (World Checklist of Selected Plant Families 2010).

Habenaria petalodes possui porte mediano e diferenciase das outras espécies do gênero na área de estudo por apresentar as pétalas laterais indivisas e com o ápice truncado. Segundo Batista et al. (2004) esta espécie alcança grande abrangência no habitat, estando associada a campos abertos graminosos ou a bordas de florestas de galeria, porém adapta-se bem a locais perturbados, como é o caso de sua ocorrência na área estudada, onde foi coletada na beira da estrada perto do Vilarejo do Funil. Leoni (1990) e Batista et al. (2004), observaram que esta espécie exala odor durante a noite.

Habenaria pseudoglaucophylla J.A.N. Batista, R.C. Mota \& N. Abreu, Novon 18(4): 409. 2008.

Fig. 4.D-E

Terrícola, 21-31 cm compr. Caule inconspícuo, multifoliado. Folhas sésseis, rosuladas. Lâmina foliar 
membranácea, 2,1-8,3 x 0,7-1,9 $\mathrm{cm}$, estreitamente elípticas, ápice acuminado. Inflorescência racemosa, ereta, laxa, apical, 26-28,5 cm compr.; pedúnculo ca. 20 cm compr.; pedicelo 3-6 mm compr.; sépala dorsal verde amarelada, ca. 5,9 x 3,5 mm, sub-orbicular, cuculada, ápice arredondado; sépalas laterais verde-amareladas, ca. 7,8 × 3,5 mm, falciformes, levemente côncavas, margem superior revoluta, ápice agudo, múcron dorsal, subapical; pétalas bipartidas, verde amareladas, segmento anterior ca. $1,5 \times 1 \mathrm{~mm}$, oblongo, ápice arredondado, segmento posterior 4,3-4,8 x 1,8-1,7 mm, oblongo, conivente à sépala dorsal, ápice emarginado; labelo verde-amarelado, tripartido, segmentos laterais ca. $9 \mathrm{~mm}$ compr., filiformes, dentículo subapical, ápice agudo, segmento mediano ca. 9 x $1 \mathrm{~mm}$, linear, ápice truncado; cálcar ca. 1,9 cm. Frutos não vistos.

Material examinado: Minas Gerais: Rio Preto, Serra do Funil, 17.IV.2006, fl./fr. Abreu et al. 73 (CESJ); 31.III.2008, fl. Abreu et al. 196 (CESJ).

\section{Distribuição geográfica: MG (Batista et al. 2008).}

Habenaria pseudoglaucophylla diferencia-se das outras espécies de Habenaria da Serra Negra principalmente por apresentar folhas rosuladas, agrupadas na base do caule curto. Ocorre em área campestre, a ca. $1100 \mathrm{~m}$ de altitude, associada a afloramentos de quartzito, sendo registrada até o momento apenas no estado de Minas Gerais (Batista et al. 2008). Exceto pela área estudada, sob o domínio Atlântico, todos os demais registros estão limitados a Cadeia do Espinhaço, localizada no domínio do Cerrado. $\mathrm{Na}$ área de estudo foram encontrados alguns indivíduos em campo úmido, na borda da trilha que leva a Gruta do Funil.

Habenaria rodeiensis Barb. Rodr., Gen. Spec. Orchid. 2: 256. 1881.

Habenaria carvalhoi Ruschi, Orquid. Nov. Estad. Espirito Santo: 31. 1946.

Fig. 4.F

Terrícola, ca. $70 \mathrm{~cm}$ compr. Caule cilíndrico, ca. 48 cm compr., multifoliado. Folhas alternas, sésseis. Lâmina foliar verde, membranácea, margem inteira, ca. $9 \times 1,5 \mathrm{~cm}$, lanceoladas, ápice agudo. Inflorescência racemosa, ereta, laxa, apical, pauciflora, ca. $22 \mathrm{~cm}$ compr.; pedúnculo ca. $17 \mathrm{~cm}$ compr.; pedicelo ca. $2 \mathrm{~cm}$ compr. Frutos imaturos, glabros, perianto persistente, ca. 1,5 cm compr.

Material examinado: Minas Gerais: Rio Preto, Serra do Funil, 16.III.2007, fr., Abreu et al. 143 (CESJ).

Distribuição geográfica: estados da Região Sudeste do Brasil, BA, DF, GO, MT, PR, SC (Batista \& Bianchetti 2002), América Central, norte da América do Sul (World Checklist of Selected Plant Families 2010).
Habenaria rodeiensis é uma planta de médio porte, cujo pedicelo longo, de ca. $2 \mathrm{~cm}$ compr., permite distingui-la das outras espécies. Embora esta seja uma característica compartilhada com outras três espécies (H. tamanduensis Schltr., $H$. longipedicellata Hoehne, $H$. lehmanniana Kraenzl.), nenhuma delas ocorre na floresta atlântica (J. A. N. Batista, com. pess.), permitindo sua identificação mesmo sem a presença de flores. Foi observado um indivíduo isolado com flores passadas, em início de frutificação, em barranco na borda da trilha que leva a Gruta do Funil, em local úmido. No Distrito Federal é encontrada sob as mesmas condições ambientais (Batista \& Bianchetti 2003).

Habenaria rolfeana Schltr., Repert. Spec. Nov. Regni Veg. 27: 298. 1930.

Fig. 5.A

Terrícola, 25,5-71 cm compr. Caule cilíndrico, 15-49 cm compr., 3-foliado a multifoliado. Folhas espiraladas, sésseis. Lâmina foliar verde, membranácea, margem inteira, ca. $13 \times 0,2 \mathrm{~cm}$, linear, ápice agudo. Inflorescência racemosa, ereta, laxa, apical, pauciflora, 10-18 cm compr.; pedúnculo ca. 9,5 cm compr.; pedicelo ca. $5 \mathrm{~mm}$ compr.; sépala dorsal verde-claro, ca. 6 × 5 $\mathrm{mm}$, largamente ovado, ápice agudo; sépalas laterais verde-claro, ca. 7 × $6 \mathrm{~mm}$, falciformes, ápice agudo; pétalas bipartidas, verde-amarelado, segmento anterior ca. $9 \mathrm{~mm}$ compr., filiforme, segmento posterior ca. $5 \mathrm{x}$ $2 \mathrm{~mm}$, falciforme, ápice agudo; labelo verde-amarelado, tripartido, segmentos laterais ca. $1 \mathrm{~cm}$ compr., filiformes, segmento mediano ca. $8 \mathrm{~mm}$ compr., linear, cálcar ca. $1,5 \mathrm{~cm}$ compr. Fruto não visto.

Material examinado: Minas Gerais: Rio Preto, Serra Negra, 22.IV.2005, Abreu et al. 20 (CESJ); 26.II.2006, bot., Viana \& Mota 1906 (CESJ); 18.V.2006, fl., Abreu et al. 96 (CESJ).

Distribuição geográfica: estados da Região Sudeste do Brasil e Paraná (Pabst \& Dungs 1975, Batista \& Bianchetti 2002).

Foram encontrados indivíduos de pequeno a médio porte, formando população de tamanho considerável (30-40 indivíduos), somente nas partes mais altas da área de estudo, em campo úmido. Os segmentos medianos do labelo e o segmento anterior da pétala são projetados para cima, como em $H$. warmingii, porém não tão longos como nesta, além de apresentarem porte menor.

Habenaria warmingii Rchb. f. \& Warm., Otia Bot. Hamburg.: 80. 1881.

Habenaria riedelii Cogn., Fl. bras. 3(4): 80. 1893.

Fig. 5.B

Terrícola, ca. $61,5 \mathrm{~cm}$ compr. Caule cilíndrico, ca. $37 \mathrm{~cm}$ compr., multifoliado. Folhas espiraladas, sésseis. Lâmina foliar membranácea, margem inteira, ca. $1,8 \times 2,5 \mathrm{~cm}$, lanceolada, 


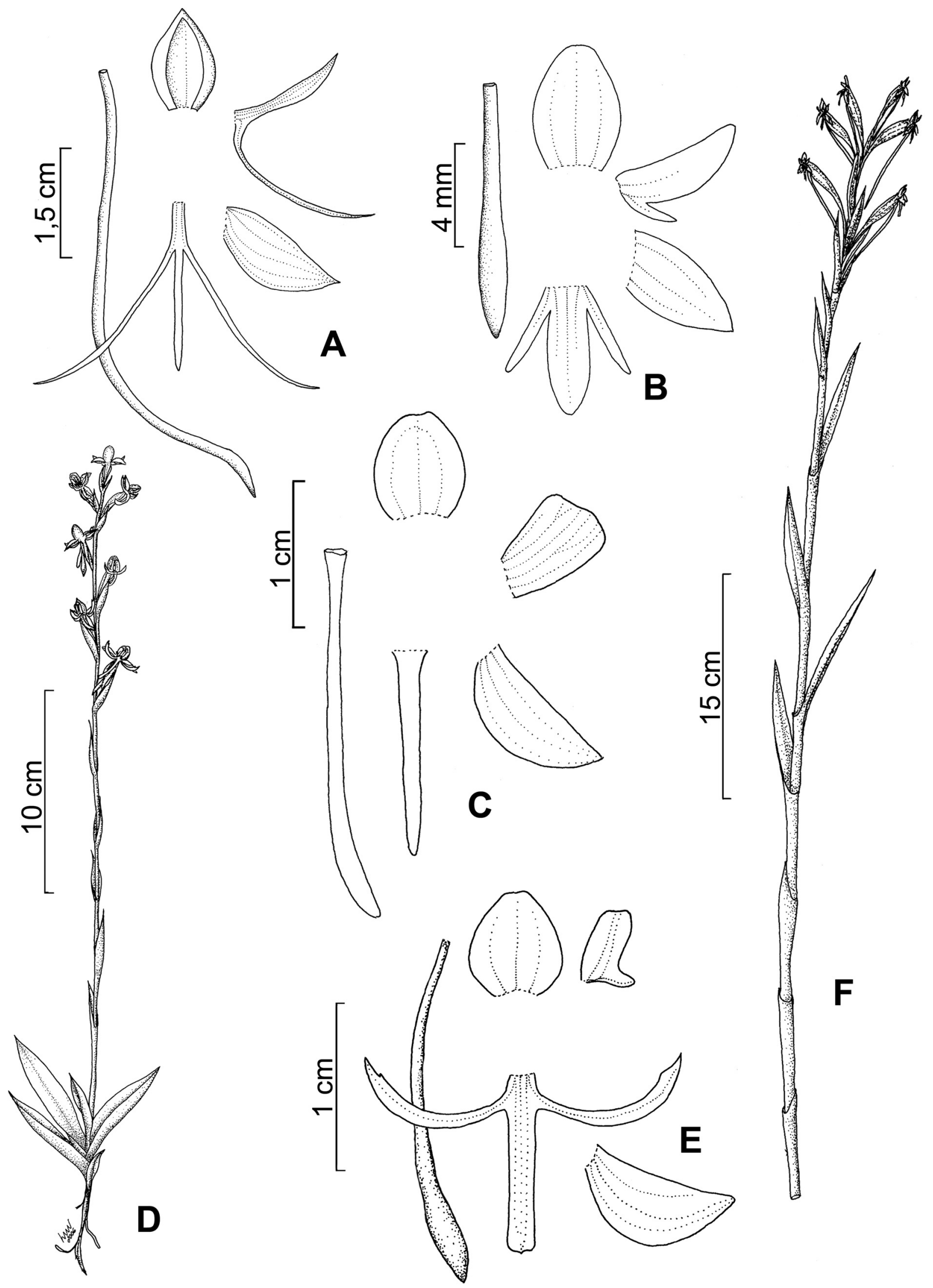

Fig. 4. Subfamília Orchidoideae: A. Habenaria macronectar - perianto dissecado; B. H. parviflora - perianto dissecado; C. H. petalodes - perianto dissecado; D-E. H. pseudoglaucophylla - D. aspecto geral, E. perianto dissecado; F. Habenaria rodeiensis - aspecto geral. (A. Salimena \& Nobre 2369; B. Menini Neto et al. 293; C. Abreu et al. 75; D- E. Abreu et al. 73; F. Abreu et al. 143). 
ápice agudo. Inflorescência racemosa, ereta, laxa, apical, multiflora, ca. $24,5 \mathrm{~cm}$ compr.; pedúnculo ca. $5,5 \mathrm{~cm}$ compr.; pedicelo ca. $8 \mathrm{~mm}$ compr.; sépala dorsal verde-escuro, ca. $7 \mathrm{x}$ $4 \mathrm{~mm}$, ovada, ápice agudo; sépalas laterais verde-escuro, ca. $8 \times 3 \mathrm{~mm}$, lanceoladas, ápice mucronado; pétalas bipartidas verde-claras, segmento anterior ca. 2,7 cm compr., filiforme, segmento posterior ca. $9 \times 1 \mathrm{~mm}$, falciforme, ápice agudo; labelo verde-claro, tripartido, segmentos laterais ca. $2,2 \mathrm{~cm}$ compr. filiformes, segmento mediano ca. $8 \mathrm{~mm}$ compr., linear; cálcar ca. 2,3 cm compr. Fruto não visto.

Material examinado: Minas Gerais: Rio Preto, Serra Negra, 22.II.2004, fl., Assis et al. 980 (CESJ).

Distribuição geográfica: estados das regiões Sul e Sudeste do Brasil (Batista \& Bianchetti 2002), Bolívia até a Argentina (World Checklist of Selected Plant Families 2010).

Possui porte mediano, diferenciando-se das outras espécies de Habenaria por apresentar o segmento anterior da pétala e os segmentos laterais do labelo, filiformes, longos e voltados para cima. $\mathrm{Na}$ área de estudo, $H$. warmingii foi coletada na Fazenda Tiririca, em local alagado no período chuvoso, no interior da mata. Em Macaé de Cima esta espécie é encontrada em locais muito úmidos, mas nunca alagados (Miller \& Warren 1996). Freqüentemente identificada como H. riedelii, considerado sinônimo (Batista \& Bianchetti 2002).

Lankesterella ceracifolia Ames, Notizbl. Bot. Gart. Berlin-Dahlem 15: 217. 1940.

Fig. 5.C

Epífita, cespitosa, ca. $2 \mathrm{~cm}$ compr. Caule inconspícuo, paucifoliado, geralmente 4-foliado. Folhas rosuladas, sésseis. Lâmina foliar glauca, membranácea, ciliada, ca. 2 x $0,5 \mathrm{~cm}$, oblanceolada, ápice agudo. Inflorescência uniflora, curva, apical, ca. $2 \mathrm{~cm}$ compr.; pedúnculo inconspícuo; pedicelo inconspícuo; sépala dorsal alva, ca. $1,2 \times 0,3 \mathrm{~cm}$, lanceolada, face abaxial pilosa, ápice agudo; sépalas laterais alvas, ca. $1,8 \times 0,25 \mathrm{~cm}$, lanceoladas, adnatas ao pé da coluna formando mento, levemente assimétricas, face abaxial pilosa, ápice agudo; pétalas alvas, ca. $1,2 \times 0,3 \mathrm{~cm}$, oblanceoladas, assimétricas, coniventes à sépala dorsal, ápice agudo; labelo alvo com estrias verdes, ca. 1,8 x $1 \mathrm{~cm}$, panduriforme, ápice arredondado. Fruto não visto.

Material examinado: Minas Gerais: Rio Preto, Serra Negra, 26.II.2006, fl., Viana \& Mota 1903 (CESJ).

Distribuição geográfica: RJ, SP, PR, SC, RS, MG (Pabst \& Dungs 1975), Argentina (World Checklist of Selected Plant Families 2010).

Espécie vegetativamente semelhante a Eurystyles actinosophila, com folhas rosuladas e glaucas, porém podem ser diferenciadas facilmente pelo tamanho e morfologia das flores, além de L. ceracifolia possuir inflorescência uniflora e $E$. actinosophila possuir inflorescência em capítulo. Lankesterella ceracifolia foi coletada somente em floresta nebular na região do Burro de Ouro, condição de alta umidade semelhante à Serra dos Órgãos, onde também pode ser encontrada (Miller et al. 2006).

Mesadenus glaziovii (Cogn.) Schltr. Beih. Bot. Centralbl. 37(2): 368. 1920.

Fig. 5.D-E

Terrícola, ca. $19 \mathrm{~cm}$ compr. Caule inconspícuo, 3-foliado. Folhas rosuladas, pseudopecioladas; pseudopecíolo ca. 5 $\mathrm{mm}$ compr. Lâmina foliar verde clara com a face adaxial maculada de creme, membranácea, margem inteira, 5-7 x 1,7-3 cm, elíptica, ápice agudo. Inflorescência em espiga, ereta, laxa, apical, ca. $19 \mathrm{~cm}$ compr.; pedúnculo ca. 13,5 cm compr.; pedicelo ca. $2 \mathrm{~mm}$ compr.; sépala dorsal creme, ca. $4 \times 1,5 \mathrm{~mm}$, lanceolada, cuculada, involuta e pilosa na face abaxial, ápice agudo; sépalas laterais cremes, ca. 5 x 1,3 $\mathrm{cm}$, de lanceoladas a elípticas, involutas, adnatas ao pé da coluna formando mento, pilosas na face adaxial, ápice agudo; pétalas creme, ca. $4 \times 1 \mathrm{~mm}$, elípticas, involutas, conivente com a sépala dorsal, ápice agudo; labelo creme, ca. $6 \times 2 \mathrm{~mm}$, estreitamente elíptico, recurvado, duas projeções ca. $0,5 \mathrm{~mm}$ compr., semi-cilíndricas, próximas à base, retrorsas, ápice agudo. Fruto não visto.

Material examinado: Minas Gerais: Rio Preto, Serra do Funil, 18.III.2007, fl., Menini Neto et al. 364 (CESJ). 2004).

Distribuição geográfica: BA, MG, RJ (Barros \& Pinheiro

Foi encontrado apenas um indivíduo isolado de $M$. glaziovii, na Fazenda da Água Amarela, em serrapilheira no interior de mata, próximo ao curso d'água, ambiente diferente daquele citado por Barros \& Pinheiro (2004) para esta espécie, em Grão Mogol, onde ocorre em campo rupestre, sobre solo arenoso. Pode ser diferenciada vegetativamente das espécies registradas na área de estudo por possuir folhas verde-claras, maculadas de creme na face adaxial.

Prescottia montana Barb. Rodr., Gen. Sp. Orchid. 1: 178. 1877.

Fig. 5.F

Terrícola 61-69 cm compr. Caule inconspícuo, unifoliado. Folha pseudopeciolada; pseudopecíolo ca. $8 \mathrm{~cm}$ compr. Lâmina foliar verde-escura, cartácea, margem inteira, ca. $12 \mathrm{x}$ $2,5 \mathrm{~cm}$, estreitamente elíptica, ápice agudo. Inflorescência em espiga, ereta a levemente curva, laxa, apical, multiflora, 61$69 \mathrm{~cm}$ compr.; pedúnculo 45,5-48 cm compr.; sépala dorsal verde, ca. 4 × $1 \mathrm{~mm}$, lanceolada, fortemente recurvada, ápice agudo; sépalas laterais verdes, ca. $5 \times 1 \mathrm{~mm}$, lanceoladas, fortemente recurvadas, ápice agudo; pétalas verdes, ca. $4 \mathrm{x}$ $0,5 \mathrm{~mm}$, obovadas ou estreitamente oblongas, fortemente recurvadas, ápice arredondado; labelo verde, ca. $6 \times 3 \mathrm{~mm}$, cuculado, margem involuta, dois apêndices basais, retrorsos, ca. $0,5 \mathrm{~cm}$ compr., ápice arredondado. Fruto não visto. 
Material examinado: Minas Gerais: Rio Preto, Serra do Funil, 21.IV.2004, fl., Salimena et al. 1329 (CESJ); Serra Negra, 22.IV.2005, bot., Abreu et al. 21 (CESJ); 18.IV.2006, fl., Menini Neto et al. 182 (CESJ); 21.V.2006, fl., Santiago et al. 6 (CESJ).

Distribuição geográfica: ES, RJ, SP, PR, SC, MG (Pabst \& Dungs 1975, World Checklist of Monocots, 2004).

Foram coletados indivíduos isolados de $P$. montana em várias altitudes na área de estudo, desde o entorno da Gruta do Funil, a ca. 900 m.s.m., até a região do Burro de Ouro, a ca. 1700 m.s.m., e também ao longo da trilha que leva ao Ninho da Égua, em torno de 1300 m.sm., porém sempre associada às áreas campestres. Pode ser distinguida das outras espécies do gênero por apresentar o caule unifoliado.

Prescottia phleoides Lindl., Gen. Sp. Orchid. Pl. 453. 1840. Fig. 5.G

Terrícola, ca. $48 \mathrm{~cm}$ compr. Caule inconspícuo, 3-foliado. Folha pseudopeciolada; pseudopecíolo ca. $4,5 \mathrm{~cm}$ compr. Lâmina foliar verde, membranácea, margem inteira, ca. 16,5 x 3,1 cm, espatulada, ápice agudo. Inflorescência em espiga, ereta, laxa, lateral, multiflora, ca. 47,5 cm compr.; pedúnculo ca. 42,5 cm compr.; sépala dorsal verde ca. 2,5 x $1 \mathrm{~mm}$, ovada, fortemente recurvada, ápice agudo; sépalas laterais verdes, ca. 2 x 1,5 mm, ovadas, fortemente recurvadas, ápice agudo; pétalas verdes, ca. $2 \times 0,7 \mathrm{~mm}$, ovadas, fortemente recurvadas, ápice agudo; labelo verde, ca. 2 x 1,5 cm, cuculado, margem involuta, dois apêndices basais, retrorsos, ca. 0,2 mm compr., ápice arredondado. Fruto não visto.

Material examinado: Minas Gerais: Rio Preto, Serra Negra, 22.VIII.2006, fl., Abreu et al. 105 (CESJ).

Distribuição geográfica: MG (Pabst \& Dungs 1975, World Checklist of Selected Plant Families 2010).

Espécie coletada somente em área de campo. Pode ser diferenciada de $P$. stachyodes e $P$. montana por seu porte menor e folhas membranáceas, além de suas flores menores.

Prescottia stachyodes (Sw.) Lindl., Edwards's Bot. Reg. 22: t. 1915. 1836.

Prescottia colorans Lindl., Edwards's Bot. Reg. 22: t. 1915. 1836.

Prescottia galeottii Rchb.f., Linnaea 19: 377. 1846.

Prescottia longipetiolata Barb.Rodr., Gen. Spec. Orchid. 1: 177.1877.

Prescottia paulensis Cogn., Fl. bras. 3(6): 548. 1906.

Prescottia longifolia Schltr., Repert. Spec. Nov. Regni Veg. Beih. 7: 51. 1920.

Prescottia smithii Schltr., Repert. Spec. Nov. Regni Veg. Beih. 7: 52. 1920.

Prescottia colorans var. macrophylla Hoehne, Revista Soc. Brasil. Agron. 8(2): 222. 1945.

Fig. 6.A
Terrícola, ca. $75 \mathrm{~cm}$ compr. Caule inconspícuo, 3-foliado. Folha pseudopeciolada, pseudopecíolo 9-11 cm compr. Lâmina foliar verde, matizada de verde-claro com a margem alva, cartácea, margem inteira, 12,7-16 x 4-5,5 cm, estreitamente elíptica, ápice agudo. Inflorescência em espiga, ereta, laxa, lateral, multiflora, ca. $74,5 \mathrm{~cm}$ compr.; pedúnculo ca. 50,5 cm compr.; sépala dorsal verde-claro, ca. 3,5 x 1,5 $\mathrm{mm}$, ovada, fortemente recurvada, ápice agudo; sépalas laterais verde-claras, ca. $4 \times 1,5 \mathrm{~mm}$, estreitamente ovadas, levemente assimétricas, fortemente recurvadas, ápice agudo; pétalas verde-claras, ca. 4 × $0,7 \mathrm{~mm}$, lanceoladas, fortemente recurvadas, ápice arredondado; labelo verde-claro, ca. 5 x $3 \mathrm{~mm}$, cuculado, margem involuta, ápice agudo. Fruto não visto.

Material examinado: Minas Gerais: Rio Preto, Serra do Funil, 22.I.2006, fl., Menini Neto et al. 233 (CESJ).

Distribuição geográfica: Região Neotropical (Pabst \& Dungs 1975, World Checklist of Selected Plant Families 2010).

Observada nas regiões da Gruta do Funil e Ninho da Égua, em borda de mata. Batista \& Bianchetti (2003), Rocha \& Waechter (2006) e Menini Neto et al. (2004a, 2007) observaram sua associação com as matas, contudo o grau de umidade parece não influenciar sua ocorrência, uma vez que no Distrito Federal P. stachyodes ocorre nas matas secas, no Rio Grande do Sul é encontrada nas florestas paludosas de restinga e em florestas pluviais de planície, na Reserva Biológica da Represa do Grama em Floresta Estacional Semidecidual e no Parque Estadual do Ibitipoca em florestas nebulares. O maior porte, as folhas verdes matizadas de verde-claro, com uma estreita listra alva na margem são características que a diferencia das outras espécies de Prescottia da área de estudo.

Sacoila lanceolata (Aubl.) Garay, Bot. Mus. Leafl. 28: 352. 1980 (publ. 1982).

Stenorrhynchos lanceolatum (Aubl.) Rich., De Orchid. Eur.: 37. 1817.

Stenorrhynchos australe Lindl., Gen. Sp. Orchid. Pl.: 477. 1840.

Stenorrhynchos coccineum (Vell.) Hoehne, Arq. Bot. Estado São Paulo 2: 146. 1952.

Fig. 6.B

Terrícola, ca. $32 \mathrm{~cm}$ compr. Caule inconspícuo, áfilo na antese. Inflorescência racemosa, ereta, laxa, apical, margem inteira, ca. $32 \mathrm{~cm}$ compr.; pedúnculo ca. $23 \mathrm{~cm}$ compr.; pedicelo ca. $4 \mathrm{~mm}$ compr.; sépala dorsal rósea, ca. $1,5 \times 0,5 \mathrm{~cm}$, lanceolada, pilosa na face abaxial, ápice agudo; sépalas laterais róseas, ca. 1,8 x 0,3 cm, lanceoladas, pilosa na face abaxial, levemente assimétricas, parcialmente conadas e adnatas ao pé da coluna, formando mento, ápice agudo; pétalas róseas, ca. 1,3 x $0,3 \mathrm{~cm}$, elípticas, assimétricas, ápice agudo; labelo róseo, ca. $1,7 \times 0,5 \mathrm{~cm}$, rômbico, piloso na base, ápice agudo. Fruto com perianto persistente, estrigoso, ca. $1 \mathrm{~cm}$ compr. 

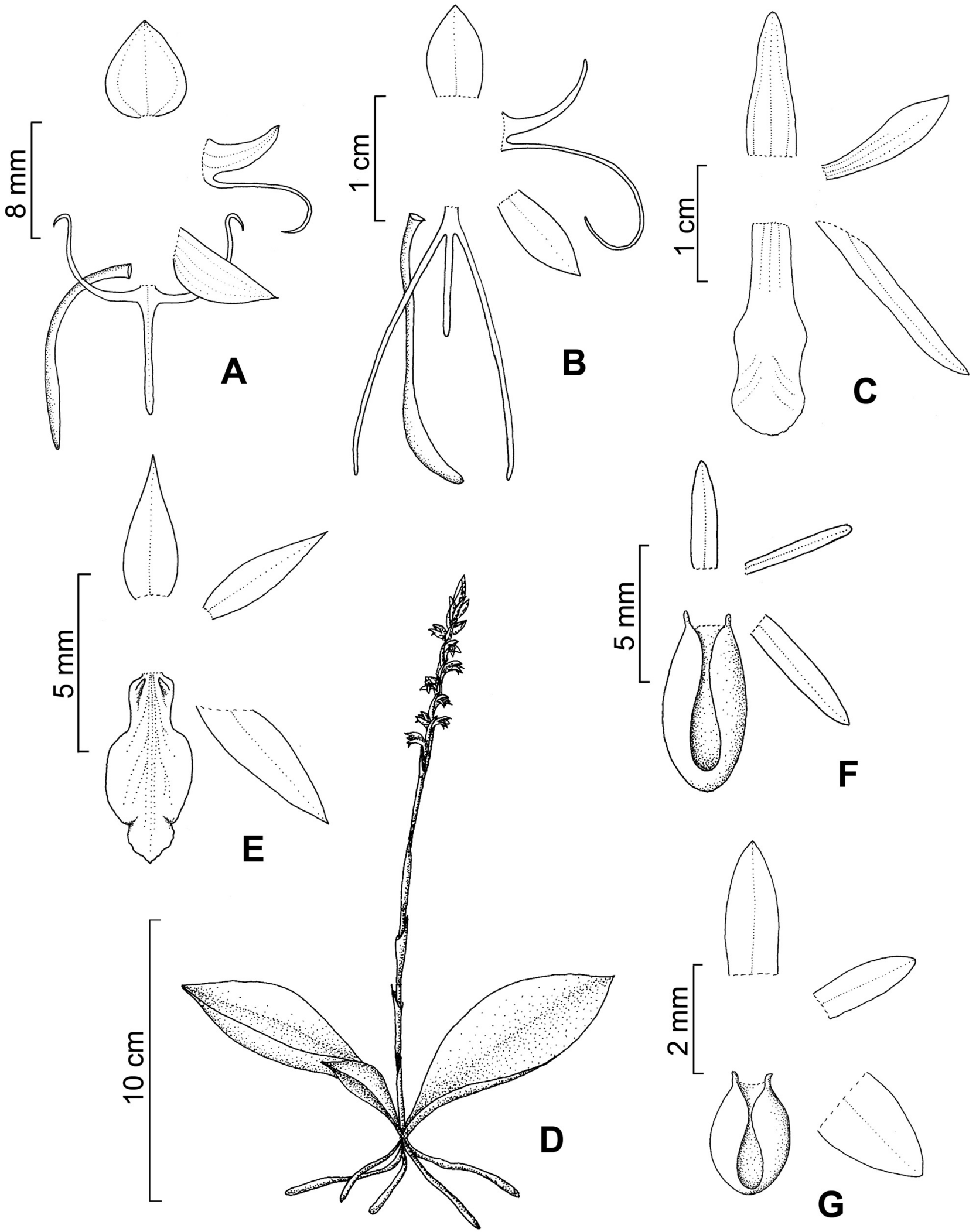

Fig. 5. Subfamília Orchidoideae: A. Habenaria rolfeana-perianto dissecado; B. H. warmingii-perianto dissecado; C. Lankesterella ceracifolia - perianto dissecado; D-E. Mesadenus glaziovii - D. aspecto geral, E. perianto dissecado; F. Prescottia montana - perianto dissecado; G. P. phleoides - perianto dissecado. (A. Abreu et al. 96; B. Assis et al. 980; C. Viana \& Mota 1903; D-E. Menini Neto et al. 364 ; F. Salimena et al. 1329; G. Abreu et al. 105). 
Material examinado: Minas Gerais: Rio Preto, Serra Negra, 21.VIII.2004, bot., Matozinhos et al. 54 (CESJ); 09.XI.2006, fl./fr., Abreu et al. 35 (CESJ).

Distribuição geográfica: Região Neotropical (Pabst \& Dungs 1975, World Checklist of Selected Plant Families 2010).

Sacoila lanceolata foi coletada ao longo da borda da trilha que leva à região do Ninho da Égua, e observada no entorno da Gruta do Funil, além da Fazenda Mato Limpo, sempre em campo. Rocha \& Waechter (2006), destacam sua preferência por ambientes antropizados, no litoral norte do Rio Grande do Sul, característica comprovada pelo seu registro nos gramados do campus da Universidade Federal de Juiz de Fora (Santiago \& Menini Neto 2006). A cor rósea de suas flores é a característica mais marcante para diferenciá-la das demais Orchidoideae registradas na área de estudo, além da ausência de folhas no período de floração.

Sarcoglottis umbrosa (Barb. Rodr.) Schltr., Beih. Bot. Centralbl. 37(2): 422. 1920.

Fig. 6.C

Terrícola, ca ca. $62 \mathrm{~cm}$ compr. Caule inconspícuo, 2-foliado. Folha pseudopeciolada, pseudopecíolo ca. $21 \mathrm{~cm}$ compr. Lâmina foliar verde, membranácea, margem inteira, ca. $12 \times 3,5 \mathrm{~cm}$, elíptica, ápice agudo. Inflorescência racemosa, ereta, laxa, apical, multiflora, ca. $62 \mathrm{~cm}$ compr.; pedúnculo ca. $55 \mathrm{~cm}$ compr.; pedicelo ca. $5 \mathrm{~mm}$ compr. Frutos estrigosos, ca. $1,5 \mathrm{~cm}$ compr., perianto caduco.

Material examinado: Minas Gerais: Rio Preto, Serra Negra, 21.V.2006, fr., Santiago et al. 12 (CESJ).

\section{Distribuição geográfica: MG (Pabst \& Dungs 1975).}

Apenas um indivíduo isolado foi observado na trilha que leva a região do Burro de Ouro. O único indivíduo coletado de $S$. umbrosa estava em período de frutificação, porém sua identificação e diferenciação das demais espécies puderam ser obtidas pelas características vegetativas marcantes, principalmente pelas folhas que apresentam um longo pseudopecíolo, ca. $21 \mathrm{~cm}$ compr.

Sauroglossum nitidum (Vell.) Schltr., Beih. Bot. Centralbl. 37(2): 376. 1920.

Sauroglossum elatum Lindl., Edwards's Bot. Reg. 19: t. 1618. 1833.

Fig. 6.D

Terrícola, ca. $81 \mathrm{~cm}$ compr. Caule inconspícuo, multifoliado. Folha pseudopeciolada; pseudopecíolo ca. $8 \mathrm{~cm}$ compr. Lâmina foliar verde, cartácea, margem inteira, 20-26 x 5-5,5 cm, estreitamente elíptica, ápice agudo. Inflorescência racemosa, ereta, laxa, apical, multiflora, ca. $81 \mathrm{~cm}$ compr.; pedúnculo ca. $50 \mathrm{~cm}$ compr.; pedicelo ca. 3,5 mm compr.; sépala dorsal verde, ca. 1 x 0,3 cm, estreitamente obovada, côncava, estrigosa na face abaxial, ápice agudo; sépalas laterais verdes, ca. 1,4 x 0,3 $\mathrm{cm}$, estreitamente obovadas, estrigosas na face abaxial, ápice agudo; pétalas verdes, ca. $1,2 \times 0,2 \mathrm{~cm}$, espatuladas, levemente assimétricas, coniventes a sépala dorsal, ápice agudo; labelo alvo, ca. $1,4 \times 0,4 \mathrm{~cm}$, estreitamente oblongo, carnoso, comprimido lateralmente, dois apêndices basais, retrorsos, ca. $2 \mathrm{~mm}$ compr., ápice arredondado, recurvado e crenulado. Fruto não visto.

Material examinado: Minas Gerais: Rio Preto, Serra Negra, fl. cult. XI.2007, fl., Souza et al. 286 (CESJ).

Distribuição geográfica: estados das reigões Sul e Sudeste do Brasil até a Argentina, Colômbia ao Equador (Pabst \& Dungs 1975, World Checklist of Selected Plant Families 2010).

Foram observados indivíduos isolados em área de campo, interior e borda de mata, tanto na parte mais baixa da área estudada, próximo à Gruta do Funil, quanto nas cotas mais altas, na trilha que leva ao Ninho da Égua. Diferencia-se das demais espécies de Orchidoideae pelas folhas e inflorescência longas e pela morfologia floral.

Stigmatosema polyaden (Vell.) Garay, Bot. Mus. Leafl. 28: 377. 1982.

Cyclopogon polyaden (Vell.) F.S. Rocha \& Waechter, Acta Bot. Brasil. 20: 78. 2006.

Cyclopogon chloroleucus Barb. Rodr., Gen. Spec. Orchid. 1: 3.1877.

Fig. 6.E

Terrícola, ca. 26,5 cm compr. Caule inconspícuo, multifoliado. Folhas rosuladas, pseudopecioladas; pseudopecíolo ca. $1 \mathrm{~cm}$ compr. Lâmina foliar verde escura, variegada, cartácea, margem inteira, 2,5-3,5 x 1-1,5 cm, elíptica, ápice agudo. Inflorescência racemosa, ereta, laxa, apical, multiflora, espiralada, ca. $26,5 \mathrm{~cm}$ compr.; pedúnculo ca. $21 \mathrm{~cm}$ compr.; pedicelo ca. $3 \mathrm{~mm}$ compr.; sépala dorsal ca. $5 \times 2 \mathrm{~mm}$, lanceolada com uma constrição próxima da base, face abaxial estrigosa na base, ápice agudo; sépalas laterais ca. $6 \times 2 \mathrm{~mm}$, oblanceoladas, levemente assimétricas, face abaxial estrigosa na base, ápice agudo; pétalas assimétricas, ca. $4 \mathrm{x}$ $0,8 \mathrm{~mm}$, ligulada, ápice arredondado; labelo ca. $6 \times 3 \mathrm{~mm}$, panduriforme, margem involuta, duas projeções chifriformes próximas à base, ápice expandido e obcordado. Fruto não visto.

Material examinado: Minas Gerais: Rio Preto, Serra do Funil, 17.IV.2006, fl., Abreu et al. 77 (CESJ).

Distribuição geográfica: estados das regiões Sudeste e Sul do Brasil, até a Argentina (Pabst \& Dungs 1975, World Checklist of Selected Plant Families 2010).

Stigmatosema polyaden foi encontrada somente na floresta de grota do Cânion do Funil, região mais baixa da área de estudo, em mata de encosta. É facilmente reconhecida por características vegetativas, como número e padrão de coloração das folhas com faixas longitudinais verde-claras e verde-escuras alternadas. 


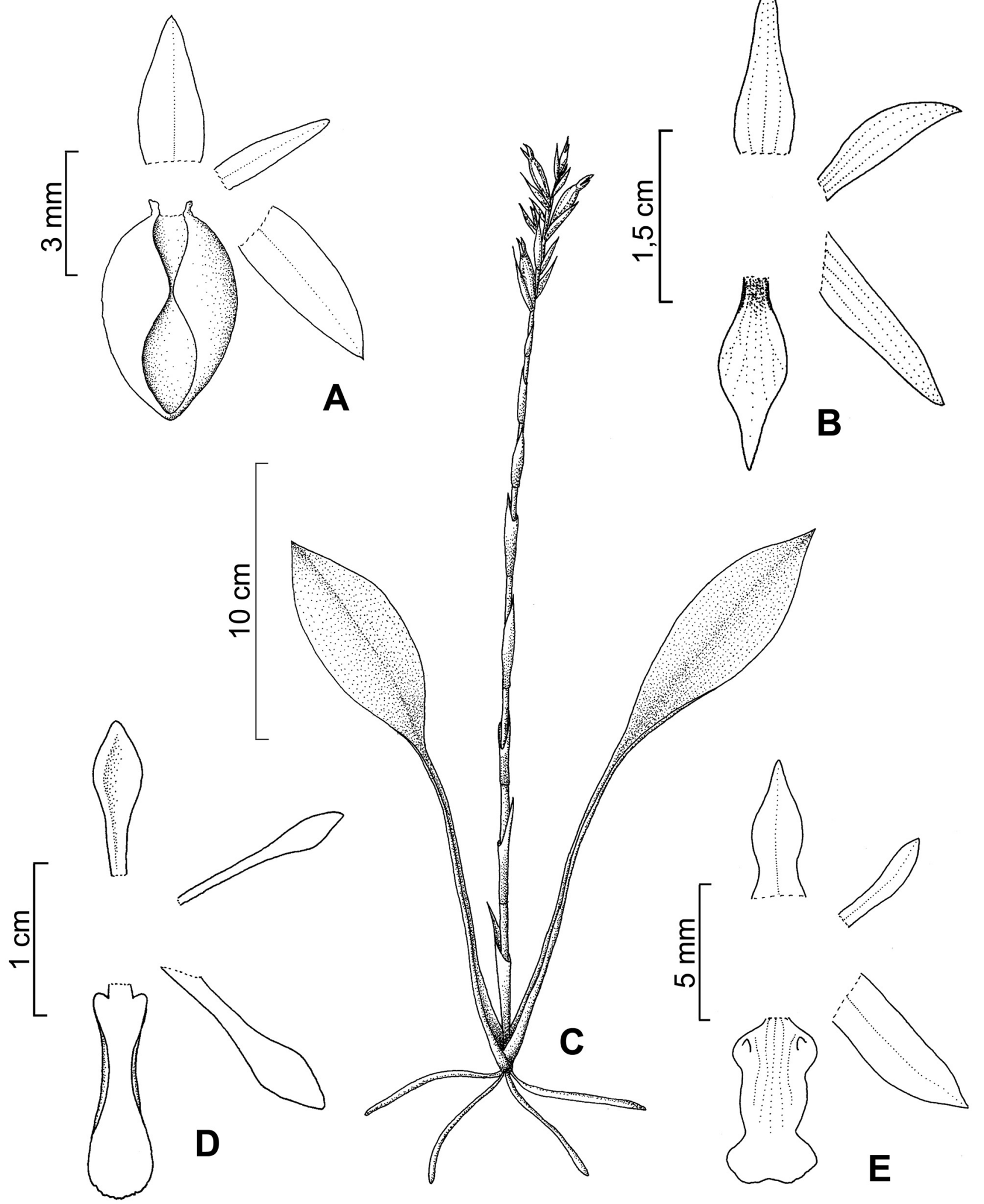

Fig. 6. Subfamília Orchidoideae: A. Prescottia stachyodes - perianto dissecado; B. Sacoila lanceolata - perianto dissecado; C. Sarcoglottis umbrosa - aspecto geral; D. Sauroglossum nitidum - perianto dissecado; E. Stigmatosema polyaden - perianto dissecado. (A. Menini Neto et al. 233; B. Abreu et al. 35; C. Santiago et al. 12; D. Souza et al. 286; E. Abreu et al. 77). 


\section{Agradecimentos}

À FAPEMIG pela concessão de auxílio (CRA 1891/06 e CRA 1810-5.02/07) e pela concessão de bolsa de Iniciação Científica a N. L. Abreu. Ao Dr. João Aguiar Nogueira Batista pelos dados e auxílio na identificação das espécies de Habenaria. O segundo autor realiza programa de Doutorado da Escola Nacional de Botânica Tropical do Instituto de Pesquisas Jardim Botânico do Rio de Janeiro.

\section{Referências}

BARROS, F. \& PINHEIRO, F. 2004. Flora de Grão-Mogol, Minas Gerais: Orchidaceae. Bol. Bot. Univ. São Paulo 22(2): 361-383.

BATISTA, J.A.N. \& BIANCHETTI, L.B. 2002. A review of Habenaria (Orchidaceae) in Pabst \& Dungs Orchidaceae Brasilienses. Lindleyana 17(2): 75-84.

BATISTA, J.A.N. \& BIANCHETTI, L.B. 2003. Lista atualizada das Orchidaceae do Distrito Federal. Acta Bot. Bras. 17(2): 183-201.

BATISTA, J.A.N., BIANCHETTI, L.B., NOGUEIRA, R.E., PELLIZZAROI, K.F. \& FERREIRA, F.E. 2004. The genus Habenaria (Orchidaceae) in Itacolomi State Park, Minas Gerais, Brazil. Sitientibus, série Ciências Biológicas 4(1/2): 25-36.

BATISTA, J.A.N., MOTA, R.C., ABREU, N.L. \& MENINI NETO, L. 2008. Habenaria pseudoglaucophylla (Orchidaceae), a new species from Minas Gerais, Brazil. Novon 18(4): 409-414.

BENITES, V.M., CAIAFA, A.N., MENDONÇA, E.S., SCHAEFER, C.E. \& KER, J.C. 2003. Solos e vegetação nos complexos rupestres de altitude da Mantiqueira e do Espinhaço. Floresta e Ambiente 10(1): $76-85$.

CAMERON, K.M., CHASE, M.W., WHITTEN, W.M., KORES, P.J., JARRELL, D.C., ALBERT, V.A., YUKAMA, T., HILLS, H.G. \& GOLDMAN, D.H. 1999. A phylogenetic analysis of the Orchidaceae: Evidence from $r b c L$ nucleotide sequences. Am. J. Bot. 86(2): 208-224.

COGNIAUX, A. 1893-1896. Orchidaceae. In C.F.P. Martius, A.G. Eichler \& I. Urban (eds.) Flora brasiliensis. Frid. Fleischer. Lipsiae, Monachii, vol. 3, pars 4, p. 1-672.

COGNIAUX, A. 1898-1902. Orchidaceae. In C.F.P. Martius, A.G. Eichler \& I. Urban (eds.) Flora brasiliensis. Frid. Fleischer. Lipsiae, Monachii, vol. 3, pars 5, p. 1-664.

COGNIAUX, A. 1904-1906. Orchidaceae. In C.F.P. Martius, A.G. Eichler \& I. Urban (eds.) Flora brasiliensis. Frid. Fleischer. Lipsiae, Monachii, vol. 3, pars 6, p. 1-604.

DRESSLER, R.L. 1981. The orchids, natural history and classification. Harvard University Press. Cambridge.

DRESSLER, R.L. 1993. Phylogeny and classification of the orchid family. Dioscorides Press. Portland.

HOEHNE, F.C. 1940. Orchidaceas. In F.C. Hoehne (ed.) Flora Brasilica. Secretaria da Agricultura, Indústria e Comércio de São Paulo. São Paulo, vol. 12, parte 1, p. 1-254.

HOEHNE, F.C. 1942. Orchidaceas. In F.C. Hoehne (Ed.) Flora Brasilica. Secretaria da Agricultura, Indústria e Comércio de São Paulo. São Paulo, vol. 12, parte 6, p. 1-218.
HOEHNE, F.C. 1945. Orchidaceas. In F.C. Hoehne (Ed.) Flora Brasilica. Secretaria da Agricultura, Indústria e Comércio de São Paulo. São Paulo, vol. 12, parte 2, p. 1-389.

HOEHNE, F.C. 1949. Iconografia das Orchidaceas do Brasil. Secretaria da Agricultura. São Paulo.

HOEHNE, F.C. 1953. Orchidaceas. In F.C. Hoehne (ed.) Flora Brasilica. Secretaria da Agricultura, Indústria e Comércio de São Paulo. São Paulo, vol. 12, parte 7, p. 1-397.

HOLMGREN, P.K., \& HOLMGREN, N.H. 1998 [continuously updated]. Index Herbariorum: A global directory of public herbaria and associated staff. New York Botanical Garden's Virtual Herbarium. http://sweetgum.nybg.org/ih/. (acessado em 31 de janeiro de 2009).

LEONI, L. S. 1990. Habenaria Willd. no município de Carangola - MG. Pabstia 1(3): 25-32.

MENINI NETO, L., ALMEIDA, V.R. \& FORZZA, R.C. 2004a. A família Orchidaceae na Reserva Biológica da Represa do Grama Descoberto, Minas Gerais, Brasil. Rodriguésia 55(84): 137-156.

MENINI NETO, L., ASSIS, L.C.S. \& FORZZA, R.C. 2004b. A família Orchidaceae em um fragmento de floresta estacional semidecidual, no município de Barroso, Minas Gerais, Brasil. Lundiana 4(1): 9-27.

MENINI NETO, L., ALVES, R.J.V., BARROS, F. \& FORZZA, R.C. 2007. Orchidaceae do Parque Estadual de Ibitipoca, MG, Brasil. Acta Bot. Bras. 21(3): 687-696.

MENININ NETO, L., MATOZINHOS, C.N., ABREU, N.L., VALENTE, A.S.M., ANTUNES, K., SOUZA, F.S., VIANA, P.L. \& SALIMENA, F.R.G. 2009. Flora vascular não-arbórea de uma floresta de grota na Serra da Mantiqueira, Zona da Mata de Minas Gerais, Brasil. Biota Neotrop. 9(4): 1-14. Disponível em: http://www.biotaneotropica. org.br/v9n4/pt/download?inventory+bn01009042009+item.

MILLER, D. \& WARREN, R. 1996. Orquídeas do Alto da Serra da Mata Atlântica Pluvial do Sudeste do Brasil. Salamandra Editora. Rio de Janeiro.

MILLER, D., WARREN, R., MILLER, I.M. \& SEEHAWER, H. 2006. Serra dos Órgãos: sua história e suas orquídeas. Editora Scart. Rio de Janeiro.

MUELLER-DOMBOIS, D. \& ELLENBERG, H. 1974. Aims and methods of vegetation ecology. J. Wiley \& Sons Press. New York.

PABST, J.F.G. \& DUNGS, F. 1975. Orchidaceae Brasilienses. Band I. Kurt Schmersow. Hildesheim.

PABST, J.F.G. \& DUNGS, F. 1975. Orchidaceae Brasilienses. Band II. Kurt Schmersow. Hildesheim.

PANSARIN, E.R. 2005. Sistemática filogenética e biologia floral de Pogoniinae sul-americanas, e revisão taxonômica e análise das ceras epicuticulares do gênero Cleistes Rich. ex Lindl. (Orchidaceae). Tese de doutorado. Universidade Estadual de Campinas, Campinas.

PRIDGEON, A.M., CRIBB, P.J.; CHASE, M.W. \& RASMUSSEN, F.N. (eds.). 1999. Genera Orchidacearum: vol. 1. General Introduction, Apostasioideae, Cypripedioideae. Oxford University Press. Oxford.

PRIDGEON, A.M.; CRIBB, P.J., CHASE, M.W. \& RASMUSSEN, F.N. (eds.). 2001. Genera Orchidacearum, vol. 2. Orchidoideae (part 1). Oxford University Press. Oxford.

PRIDGEON, A.M., CRIBB, P.J., CHASE, M.W. \& RASMUSSEN, F.N. 2003. Genera Orchidacearum, vol. 3. Orchidoideae (part 2) Vanilloideae. Oxford University Press. Oxford. 
ROCHA, F.S. \& WAECHTER, J.L. 2006. Sinopse das Orchidaceae terrícolas ocorrentes no litoral norte do Rio Grande do Sul, Brasil. Acta Bot. Bras. 20(1): 71-86.

RODRIGUES, J.B. 1877. Genera et Species Orchidearum Novarum. vol. 1. Typographia Nacional. Rio de Janeiro.

RODRIGUES, J.B. 1882. Genera et Species Orchidearum Novarum. vol. 2. Typographia Nacional. Rio de Janeiro.

SANTIAGO, A.L. \& MENINI NETO, L. 2006. Ocorrência natural de Orchidaceae no campus da Universidade Federal de Juiz de Fora, Minas Gerais. In Resumos da XXIX Semana de Biologia da Universidade Federal de Juiz de Fora. Universidade Federal de Juiz de Fora, p. 140-144.
SPRUNGER, S. (ed.) 1996. João Barbosa Rodrigues - Iconographie des orchidées du Brésil. v. 1: The illustrations. Friedrich Reinhardt Verlag. Basle.

VALENTE, A.S.M. 2007. Composição, estrutura e similaridade florística do estrato arbóreo de três fragmentos de Floresta Atlântica na Serra Negra, município de Rio Preto, Minas Gerais, Brasil. Dissertação de Mestrado. Universidade Federal de Juiz de Fora, Juiz de Fora.

WORLD CHECKLIST OF SELECTED PLANT FAMILIES. 2010. The Board of Trustees of the Royal Botanical Gardens, Kew. Published on the Internet; http://www.kew.org/monocot Checklist/ (acessado em 29 de janeiro de 2010). 